\title{
Applications of a novel nano magnetic catalyst in the synthesis of 1,8 - dioxo-octahydroxanthene and dihydropyrano[2,3-c]pyrazole derivatives
}

\author{
Mohammad Ali Zolfigol, ${ }^{*}$ a Roya Ayazi-Nasrabadi, ${ }^{a}$ Saeed Baghery, ${ }^{\text {a }}$ Vahid Khakyzadeh, ${ }^{\text {baeid }}$ Azizian ${ }^{\mathrm{c}}$ \\ ${ }^{a}$ Department of Organic Chemistry, Faculty of Chemistry, Bu-Ali Sina University, Hamedan 6517838683, Iran \\ ${ }^{b}$ Faculty of Science, Department of Chemistry, K. N.Toosi University, P.O. Box 15875-4416, Tehran, I. R. Iran \\ ${ }^{c}$ Department of Physical Chemistry, Faculty of Chemistry, Bu-Ali Sina University, Hamedan 6517838683, Iran
}

*Corresponding Author: Fax: +988138380709

E-mail: zolfi@basu.ac.irandmzolfigol@yahoo.com (M.A. Zolfigol). 
Abstract: Imidazole-based ionic liquid-stabilized on silica coated $\mathrm{Fe}_{3} \mathrm{O}_{4}$ magnetic nano particles [nano- $\mathrm{Fe}_{3} \mathrm{O}_{4} @ \mathrm{SiO}_{2} @\left(\mathrm{CH}_{2}\right)_{3}$-Imidazole- $\left.\mathrm{SO}_{3} \mathrm{H}\right] \mathrm{Cl}$ as a novel heterogeneous acidic catalyst was designed, synthesized and fully characterized by FT-IR, thermo gravimetric analysis (TGA), differential thermal analysis (DTA), energy-dispersive x-ray spectroscopy (EDX), X-ray diffraction patterns (XRD), scanning electron microscopy (SEM), transmission electron microscopy (TEM), atomic force microscopy (AFM), Brunauer-Emmett-Teller (BET) and inductively coupled plasma (ICP) analysis. The nano-structured organo solid catalyst as a novel, mild and full-fledged catalyst was used for the cascade synthesis of 1,8-dioxo-octahydroxanthene derivatives by the condensation reaction between dimedone and various aldehydes at $80{ }^{\circ} \mathrm{C}$ under solvent-free conditions. Similarly, dihydropyrano[2,3-c]pyrazole derivatives were synthesized by the one-pot three-component condensation reaction of aldehydes, malononitrile and 3-methyl-1-phenyl-2-pyrazoline-5-one under solvent-free conditions at room temperature. To the knowledge of our science, this is the main investigation on the synthesis of [nano$\mathrm{Fe}_{3} \mathrm{O}_{4} @ \mathrm{SiO}_{2} @\left(\mathrm{CH}_{2}\right)_{3}$-Imidazole- $\left.\mathrm{SO}_{3} \mathrm{H}\right] \mathrm{Cl}$ as a worthy heterogeneous nano magnetic solid acid for acid catalyzed organic reactions.

Keywords: Imidazole-based ionic liquid-stabilized magnetic nano-structured particles, [nano$\mathrm{Fe}_{3} \mathrm{O}_{4} @ \mathrm{SiO}_{2} @\left(\mathrm{CH}_{2}\right)_{3}$-Imidazole- $\left.\mathrm{SO}_{3} \mathrm{H}\right] \mathrm{Cl}$, 1,8-dioxo-octahydroxanthenes, dihydropyrano[2,3c]pyrazoles, solvent-free conditions. 


\section{Introduction}

Nowadays, there is a more demand for development of ecologically sustainable approaches in fine chemical processes, pharmaceutical industries, design, synthesis and applications of various kinds of catalysts because catalysis plays a major role in the prevention of pollution in our environment [1]. The catalytic reaction is a cyclic system and separation of heterogeneous catalyst from reaction mixture is easier than homogenous one [2]. Usual heterogeneous solid acid catalysts are inorganic or hybrid of organic and inorganic materials. Solid acid catalyst should have great pores, many active acidic sites, high stability with good selectivity, recyclability and reusability, high TON and TOF and also should be economically and environmentally sustainable [3].

Magnetic nano particles (MNPs) with acidic tags have above mentioned properties. On the other hand, MNPs can be separated into four types: metals (Fe, Co, Ni), alloys (FePt, FePd), metal oxides $\left(\mathrm{FeO}, \mathrm{Fe}_{2} \mathrm{O}_{3}, \mathrm{Fe}_{3} \mathrm{O}_{4}\right)$, and ferrites $\left(\mathrm{CoFe}_{2} \mathrm{O}_{4}, \mathrm{CuFe}_{2} \mathrm{O}_{4}\right)$. Between the four types of magnetic nanoparticles, iron oxides have attracted the most attention, for the reason that they can be produced effortlessly via co-precipitation and also they have stronger magnetic properties [4$6]$.

1,8-Dioxo-octahydroxanthenes displays beneficial biological activities for instance pigments and cosmetics [7], luminescent sensors [8], fluorescent materials [9], photodynamic therapy [10], finds use in biodegradable agrochemicals $[11,12]$, antibacterial, antiviral activities, anti-inflammatory [13] and in laser technologies [14]. Additionally, these compounds have been applied in photodynamic therapy [15] and as antagonists for paralyzing the action of zoxazolamine $[16,17]$. 
Numerous processes are presented for the creation for xanthenes and benzoxanthenes including the trapping of benzynes by phenols [18], cyclocondensation reaction between 2hydroxyaromatic aldehydes and 2-tetralone [19], cycloacylation of carbamates [20], intramolecular phenylcarbonyl coupling reaction of benzaldehydes and acetophenones [21], aryloxymagnesium halides with triethylorthoformate [22], form amide [23] and carbon monoxide [24].

Pyrano[2,3-c]pyrazoles are very desirable as a type of heterocycles due to their potential uses in pharmaceutical field. They display a varied range of biological activities like antiinflammatory [25], anticancer [26, 27], inhibitors of human Chk1 kinase [28], antimicrobial [29] and also as biodegradable agrochemicals [30]. Moreover, they play a main role as essential synthetic intermediates [31]. The first method has been reported by using the base-catalyzed cyclization of 4-aryliden-5-pyrazolone [32]. New approaches for the production of pyrazole include synthesis based process of $\beta$-cyclodextrin [33], cinchona alkaloid derivatives [34], $\mathrm{Sc}(\mathrm{OTf})_{3}$ [35], triethylamine [36], water or ethanol media [37, 38], imidazole [39], $\mathrm{CuO} / \mathrm{ZrO}_{2}$ [40] and triethylbenzylammonium chloride [41].

In continuance of our researches on the design, synthesis and use of solid acids [42], inorganic acidic salts [43], nano magnetic catalysts [44] and science-based development of taskspecific ionic liquids (TSILs) [45], we decided to link all of the above mentioned experiences to design and synthesis of imidazole-based ionic liquid-stabilized on silica coated $\mathrm{Fe}_{3} \mathrm{O}_{4}$ magnetic nano particles [nano- $\mathrm{Fe}_{3} \mathrm{O}_{4} @ \mathrm{SiO}_{2} @\left(\mathrm{CH}_{2}\right)_{3}$-Imidazole- $\left.\mathrm{SO}_{3} \mathrm{H}\right] \mathrm{Cl}$ or $\left[\mathrm{MNP}-\mathrm{PIm}-\mathrm{SO}_{3} \mathrm{H}\right] \mathrm{Cl}$. Then the described catalyst was used in the synthesis of 1,8-dioxo-octahydroxanthene and dihydropyrano[2,3-c]pyrazole derivatives under solvent-free conditions (Scheme 1). 


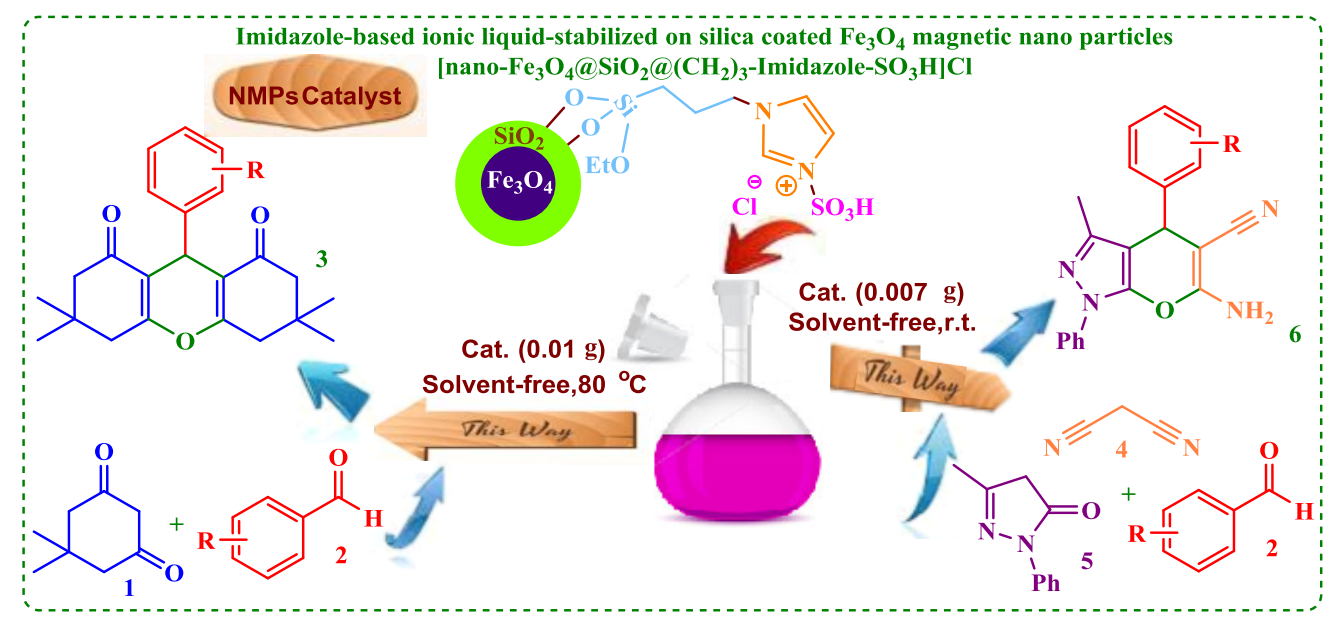

Scheme 1. The synthesis of 1,8-dioxo-octahydroxanthenes and dihydropyrano[2,3-c]pyrazole derivatives using [nano- $\mathrm{Fe}_{3} \mathrm{O}_{4} @ \mathrm{SiO}_{2} @\left(\mathrm{CH}_{2}\right)_{3}$-Imidazole- $\left.\mathrm{SO}_{3} \mathrm{H}\right] \mathrm{Cl}$ as MNPs catalyst.

\section{Experimental}

2.1. General procedure for the preparation of [nano- $\mathrm{Fe}_{3} \mathrm{O}_{4} @ \mathrm{SiO}_{2} @\left(\mathrm{CH}_{2}\right)_{3}$-Imidazole$\mathrm{SO}_{3} \mathrm{HJCl}$ as a heterogeneous acidic catalyst.

At first, magnetite phase $\mathrm{Fe}_{3} \mathrm{O}_{4}$ was produced by adding $3 \mathrm{~mL} \mathrm{FeCl}_{3}(2 \mathrm{M}$ dissolved in $2 \mathrm{M}$ $\mathrm{HCl})$ to $10.33 \mathrm{~mL}$ double distilled water followed via drop wise addition of $2 \mathrm{mLNa}_{2} \mathrm{SO}_{3}(1 \mathrm{M})$ for 3 min under magnetic stirring. After the solution color changed from red to light yellow, 80 $\mathrm{mL}$ of an $\mathrm{NH}_{3} \cdot \mathrm{H}_{2} \mathrm{O}$ solution $(0.85 \mathrm{M})$ were added under vigorous stirring. After 15 min, the magnetite precipitate $\left(\mathrm{Fe}_{3} \mathrm{O}_{4}\right)$ was washed to $\mathrm{pH}<7.5$ by distilled water and separated with a magnet [46]. $3 \mathrm{~mL}$ tetraethylorthosilicate (TEOS) was added to a mixture of $1 \mathrm{~g}$ of $\mathrm{Fe}_{3} \mathrm{O}_{4}, 20 \mathrm{~mL}$ water, $80 \mathrm{~mL}$ ethanol and $3 \mathrm{~mL}$ ammonia under reflux to attain $\mathrm{Fe}_{3} \mathrm{O}_{4}$-silica coated $\left(\mathrm{Fe}_{3} \mathrm{O}_{4} @ \mathrm{SiO}_{2}\right)$ [47]. Thus, $3 \mathrm{~g}$ of $\mathrm{Fe}_{3} \mathrm{O}_{4}$-silica coated $\left(\mathrm{Fe}_{3} \mathrm{O}_{4} @ \mathrm{SiO}_{2}\right)$ and (3-chloropropyl) triethoxysilane $(2.408 \mathrm{~g}, 10 \mathrm{mmol})$ in $80 \mathrm{~mL}$ of dry toluene were refluxed under nitrogen for 12 h. The treated $\mathrm{Fe}_{3} \mathrm{O}_{4} @ \mathrm{SiO}_{2} @\left(\mathrm{CH}_{2}\right)_{3} \mathrm{Cl}$ (grafted with chloropropyl group) was filtered, washed twice with dry toluene and anhydrous diethyl ether, and dried at $80{ }^{\circ} \mathrm{C}$ for $6 \mathrm{~h}$ in vacuum. Subsequently imidazole $(0.681 \mathrm{~g}, 10 \mathrm{mmol})$ in $50 \mathrm{~mL}$ of dry toluene was added to the 
$\mathrm{Fe}_{3} \mathrm{O}_{4} @ \mathrm{SiO}_{2} @\left(\mathrm{CH}_{2}\right)_{3} \mathrm{Cl}$ and the mixture was refluxed for $12 \mathrm{~h}$ [48]. The resulting solid was filtered, washed and dried in a same procedure to create the $\mathrm{Fe}_{3} \mathrm{O}_{4} @ \mathrm{SiO}_{2} @\left(\mathrm{CH}_{2}\right)_{3}$-Imidazole. At last, a solution of chlorosulfonic acid $(0.666 \mathrm{~mL}, 1.165 \mathrm{~g}, 10 \mathrm{mmol})$ in dry dichloromethane (10 $\mathrm{mL}$ ) was added drop wise to the suspension of $\mathrm{Fe}_{3} \mathrm{O}_{4} @ \mathrm{SiO}_{2} @\left(\mathrm{CH}_{2}\right)_{3}$-Imidazole and the reaction mixture was stirred for $6 \mathrm{~h}$. Finally, the imidazole-based ionic liquid-stabilized on silica coated $\mathrm{Fe}_{3} \mathrm{O}_{4}$ magnetic nano particles [nano- $\mathrm{Fe}_{3} \mathrm{O}_{4} @ \mathrm{SiO}_{2} @\left(\mathrm{CH}_{2}\right)_{3}$-Imidazole- $\left.\mathrm{SO}_{3} \mathrm{H}\right] \mathrm{Cl}$ was obtained after filtering, washing and drying (Scheme 2).

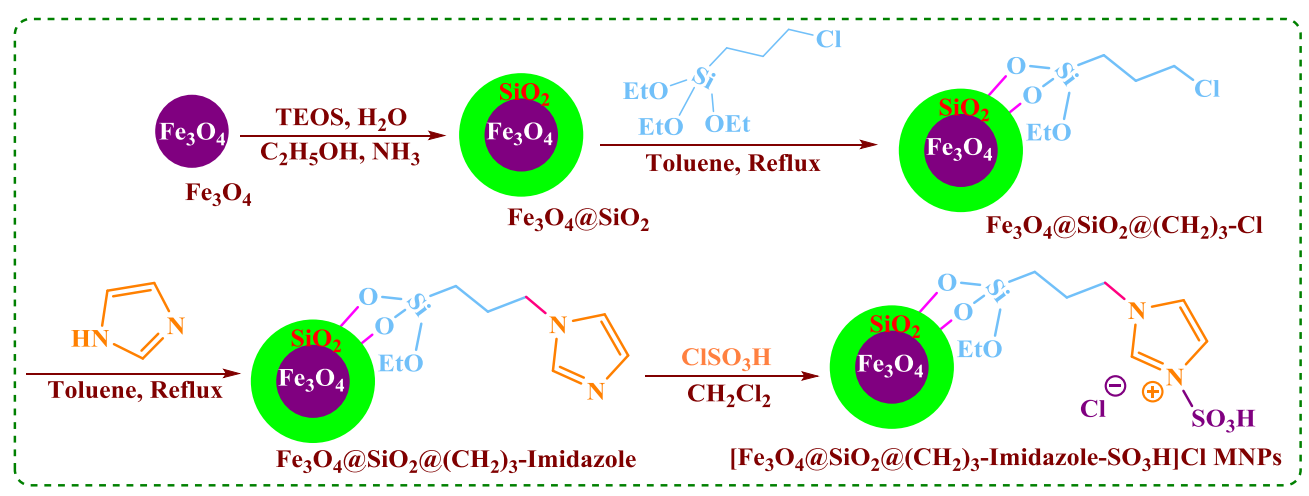

Scheme 2. The synthesis of imidazole-based ionic liquid-stabilized on silica coated $\mathrm{Fe}_{3} \mathrm{O}_{4}$ magnetic nano particles [nano- $\mathrm{Fe}_{3} \mathrm{O}_{4} @ \mathrm{SiO}_{2} @\left(\mathrm{CH}_{2}\right)_{3}$-Imidazole- $\left.\mathrm{SO}_{3} \mathrm{H}\right] \mathrm{Cl}$ as a MNPs catalyst.

\subsection{General procedure for the synthesis of 1,8-dioxo-octahydroxanthene derivatives.}

[nano- $\mathrm{Fe}_{3} \mathrm{O}_{4} @ \mathrm{SiO}_{2} @\left(\mathrm{CH}_{2}\right)_{3}$-Imidazole- $\left.\mathrm{SO}_{3} \mathrm{H}\right] \mathrm{Cl}$ as a MNPs catalyst $(10 \mathrm{mg})$ was added and mixed to a mixture of aromatic aldehyde $(1 \mathrm{mmol})$ and dimedone $(0.280 \mathrm{~g}, 2 \mathrm{mmol})$ under solvent-free conditions at $80{ }^{\circ} \mathrm{C}$ for the suitable time described in Table 3. After completion of the reaction which was identified with TLC ( $n$-hexane/ethyl acetate: 5/3), the MNPs catalyst was recovered magnetically by adding $5 \mathrm{ml}$ ethanol and the mixture was purified by recrystallization from ethanol-water (10:1), which resulted in precipitation of the expected 1,8-dioxooctahydroxanthene derivatives. All of the obtained product(s) are known and were identified by comparison of their physical data with those of reported in the literature (see Table 3). 
2.3. General procedure for the synthesis of dihydropyrano[2,3-c]pyrazole derivatives.

[nano- $\left.\mathrm{Fe}_{3} \mathrm{O}_{4} @ \mathrm{SiO}_{2} @\left(\mathrm{CH}_{2}\right)_{3}-\mathrm{Imidazole}-\mathrm{SO}_{3} \mathrm{H}\right] \mathrm{Cl}$ as a $\mathrm{MNPs}$ catalyst $(7 \mathrm{mg})$ was added and mixed to a mixture of aromatic aldehyde $(1 \mathrm{mmol})$, malononitrile $(0.066 \mathrm{~g}, 1 \mathrm{mmol})$ and 3 methyl-1-phenyl-2-pyrazoline-5-one $(0.174 \mathrm{~g}, 1 \mathrm{mmol})$ under solvent-free conditions at room temperature for the suitable time defined in Table 5. After completion of the reaction which was identified by TLC ( $n$-hexane/ethyl acetate: 5/2), The MNPs catalyst was recovered magnetically by adding $5 \mathrm{ml}$ ethanol and the product was purified via recrystallization from ethanol-water (10:1), which resulted in precipitation of the desired dihydropyrano[2,3-c]pyrazole derivatives. All of the obtained product(s) are known and were identified by comparison of their physical data with those of reported in the literature (see Table 5).

\subsection{Spectral data analysis for compounds}

9-(3,5-Dichloro-2-hydroxyphenyl)-3,3,6,6-tetramethyl-3,4,5,6,7,9-hexahydro-1H-

xanthene-1,8(2H)-dione (Table 3, entry 18): White solid; M.p. 230-232 ${ }^{\circ} \mathrm{C}$; Yield: 94\%; IR $\left(\mathrm{KBr}, \mathrm{cm}^{-1}\right): 3182,2961,1665,1648,1602,1458,1377,1314,1259,1207,1027,854,561 ;{ }^{1} \mathrm{H}$ NMR (300 MHz, DMSO- $\left.d_{6}\right): \delta 0.89\left(\mathrm{~s}, 6 \mathrm{H},-\mathrm{CH}_{3}\right), 1.06\left(\mathrm{~s}, 6 \mathrm{H},-\mathrm{CH}_{3}\right), 2.41(\mathrm{~d}, 4 \mathrm{H}, J=7.8 \mathrm{~Hz}$, $\left.-\mathrm{CH}_{2}\right), 2.63\left(\mathrm{~d}, 4 \mathrm{H}, J=8.8 \mathrm{~Hz},-\mathrm{CH}_{2}\right), 5.05(\mathrm{~s}, 1 \mathrm{H},-\mathrm{CH}$ aliphatic), $6.85(\mathrm{~s}, 1 \mathrm{H}, \mathrm{ArH}), 7.44(\mathrm{~s}$,

$1 \mathrm{H}, \mathrm{ArH}), 10.78(\mathrm{~s}, 1 \mathrm{H},-\mathrm{OH}) ;{ }^{13} \mathrm{C}$ NMR (DMSO- $\left.d_{6}\right): \delta(\mathrm{ppm}) 26.4,29.6,32.1,32.2,50.7$, 111.1, 113.0, 121.2, 127.0, 127.4, 127.9, 129.7, 145.1, 164.5, 196.1; Mass: $\mathrm{m} / \mathrm{z}(\%)=434\left(\mathrm{M}^{+}\right)$.

6-Amino-4-(3,5-dichloro-2-hydroxyphenyl)-3-methyl-1-phenyl-1,4-dihydropyrano[2,3c]pyrazole-5-carbonitrile (Table 5, entry 16): White solid; M.p. $223-225{ }^{\circ} \mathrm{C}$; Yield: 93\%; IR $\left(\mathrm{KBr}, \mathrm{cm}^{-1}\right): 3417,3322,3191,3081,2194,1652,1622,1572,1399 ;{ }^{1} \mathrm{H}$ NMR $(300 \mathrm{MHz}$, DMSO-d $\left.)_{6}\right): \delta 2.26\left(\mathrm{~s}, 3 \mathrm{H},-\mathrm{CH}_{3}\right), 4.70(\mathrm{~s}, 1 \mathrm{H},-\mathrm{CH}$ aliphatic), $7.04(\mathrm{~d}, 2 \mathrm{H}, J=9.8 \mathrm{~Hz}, \mathrm{ArH})$, $7.14(\mathrm{t}, 2 \mathrm{H}, J=7.9 \mathrm{~Hz}, \mathrm{ArH}), 7.42(\mathrm{~s}, 2 \mathrm{H}, \mathrm{ArH}), 7.55(\mathrm{t}, 1 \mathrm{H}, J=7.8 \mathrm{~Hz}, \mathrm{ArH}), 7.70(\mathrm{~s}, 2 \mathrm{H},-$ 
$\left.\mathrm{NH}_{2}\right), 11.16(\mathrm{~s}, 1 \mathrm{H},-\mathrm{OH}) ;{ }^{13} \mathrm{C}$ NMR (DMSO- $\left.d_{6}\right): \delta$ (ppm) 11.1, 30.0, 54.1, 108.8, 109.0, 118.5, $120.5,121.3,124.8,125.5,126.5,127.4,128.2,129.3,137.3,144.5,147.5,147.7,150.0,160.2$, 162.4; Mass: $\mathrm{m} / \mathrm{z}(\%)=413\left(\mathrm{M}^{+}\right)$.

\section{Results and discussion}

3.1. Characterization of imidazole-based ionic liquid-stabilized on silica coated $\mathrm{Fe}_{3} \mathrm{O}_{4}$ magnetic nano particles [nano- $\mathrm{Fe}_{3} \mathrm{O}_{4} @ \mathrm{SiO}_{2} @\left(\mathrm{CH}_{2}\right)_{3}$-Imidazole- $\left.\mathrm{SO}_{3} \mathrm{H}\right] \mathrm{Cl}$ as a heterogeneous acidic catalyst.

Recently, Gu and coworkers reported a good range of sulfonyl-containing ammoniumbased Bronsted acid ILs as efficient liquid heterogeneous catalysts for the synthesis of a wide range of organic compounds under solvent-free conditions [49]. In the same way, our research group has also reported nano-sphere silica containing of imidazole linker with sulfonic acid tag and its applications in various multi component reactions [50]. Herein, we wish to report a novel core-shell nano magnetic silica coated with imidazole spacer and sulfonic acid tag [MNP-PIm$\left.\mathrm{SO}_{3} \mathrm{H}\right] \mathrm{Cl}$.

The structure of imidazole-based ionic liquid-stabilized on silica coated $\mathrm{Fe}_{3} \mathrm{O}_{4}$ magnetic nano particles [MNP-PIm- $\left.\mathrm{SO}_{3} \mathrm{H}\right] \mathrm{Cl}$ as a heterogeneous acidic catalyst was studied and fully characterized by FT-IR, thermo gravimetric analysis (TGA), differential thermal analysis (DTA), EDX, XRD, SEM, TEM and AFM analysis.

The FT-IR spectroscopy was engaged to compare the produced blank $\mathrm{Fe}_{3} \mathrm{O}_{4}$ magnetic nano particles, $\mathrm{Fe}_{3} \mathrm{O}_{4} @ \mathrm{SiO}_{2}$ core-shell MNPs and the further core-shell surface modified samples (Fig. 1). FT-IR spectroscopy of the bare magnetic $\mathrm{Fe}_{3} \mathrm{O}_{4}$ nano particles presented a characteristic absorption peak of $\mathrm{Fe}-\mathrm{O}$ bond at about $575 \mathrm{~cm}^{-1}$. The absorption peaks of the silica shell in the $\mathrm{Fe}_{3} \mathrm{O}_{4} @ \mathrm{SiO}_{2}$ core-shell MNPs about 1090 and $780 \mathrm{~cm}^{-1}$ are linked to the anti-symmetric and 
symmetric stretching vibrations of $\mathrm{Si}-\mathrm{O}-\mathrm{Si}$ bond in oxygen-silica tetrahedral, respectively. Individually, absorption peak of the $\mathrm{Fe}_{3} \mathrm{O}_{4} @ \mathrm{SiO}_{2}$-Prop core-shell MNPs at $2987 \mathrm{~cm}^{-1}$ is related to the stretching vibration of $\mathrm{C}-\mathrm{H}$ groups. Absorption peak at $3180 \mathrm{~cm}^{-1}$ is also linked with the stretching vibration of aromatic $\mathrm{C}-\mathrm{H}$ groups on imidazole ring and the absorption peak at 1635 $\mathrm{cm}^{-1}$ is also correlated to the stretching vibration of $\mathrm{C}=\mathrm{N}$ bond on imidazole ring. Additionally, the absorption band at $3400 \mathrm{~cm}^{-1}$ illustrates stretching vibration of $\mathrm{O}-\mathrm{H}$ in the $\mathrm{SO}_{3} \mathrm{H}$ group and the peaks at $1220 \mathrm{~cm}^{-1}$ and $1073 \mathrm{~cm}^{-1}$ are linked to vibrational modes of $\mathrm{O}-\mathrm{SO}_{2}$ bonds. The absorption associated to $\mathrm{S}=\mathrm{O}$ bond vibration is observed at $1024 \mathrm{~cm}^{-1}$.

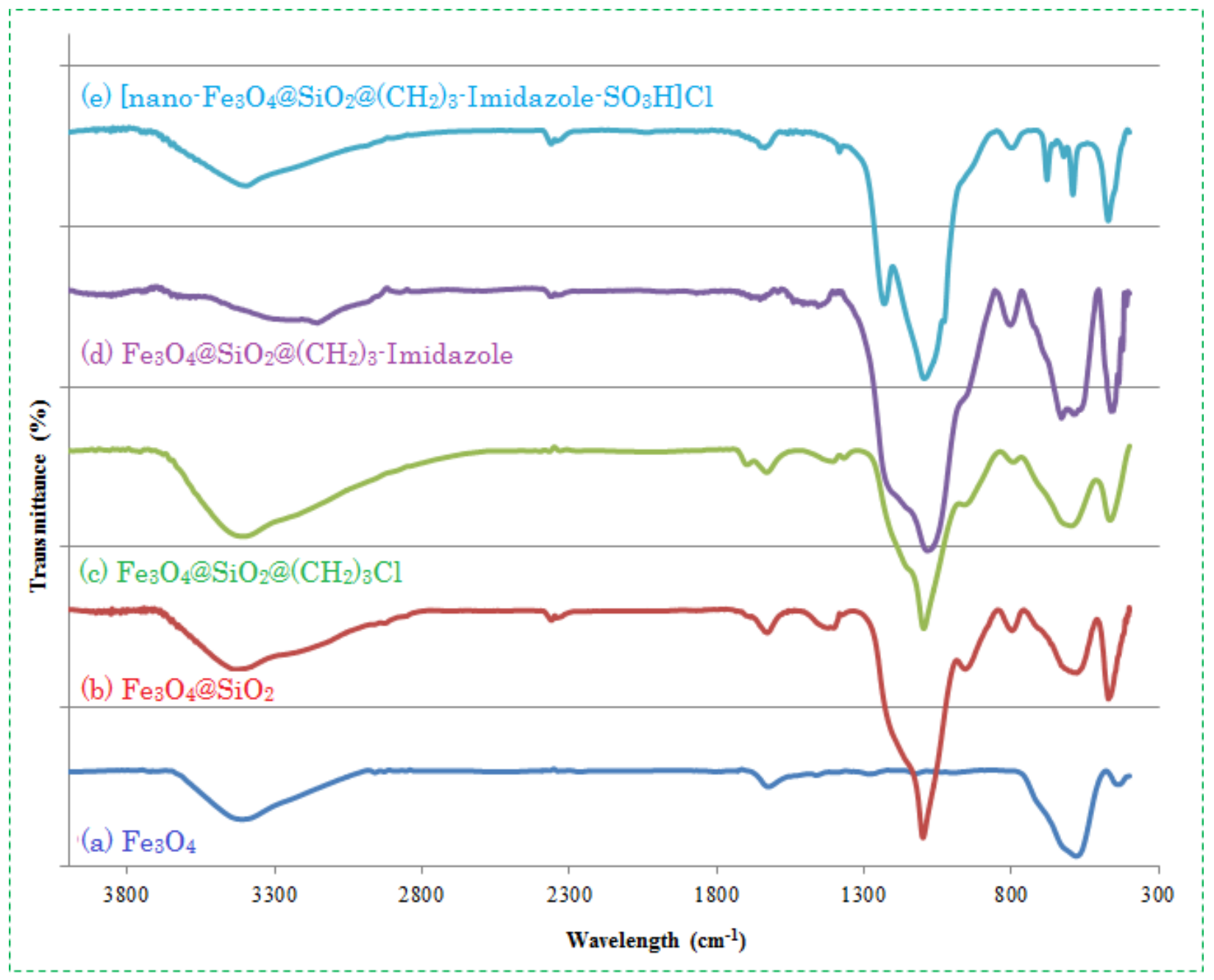


Fig. 1. The IR spectrum of (a) $\mathrm{Fe}_{3} \mathrm{O}_{4}$; (b) $\mathrm{Fe}_{3} \mathrm{O}_{4} @ \mathrm{SiO}_{2}$; (c) $\mathrm{Fe}_{3} \mathrm{O}_{4} @ \mathrm{SiO}_{2} @\left(\mathrm{CH}_{2}\right)_{3} \mathrm{Cl}$; (d) $\mathrm{Fe}_{3} \mathrm{O}_{4} @ \mathrm{SiO}_{2} @\left(\mathrm{CH}_{2}\right)_{3^{-}}$ Imidazole; (e) [nano- $\mathrm{Fe}_{3} \mathrm{O}_{4} @ \mathrm{SiO}_{2} @\left(\mathrm{CH}_{2}\right)_{3}$-Imidazole- $\left.\mathrm{SO}_{3} \mathrm{H}\right] \mathrm{Cl}$.

The thermo gravimetric analysis (TGA) and differential thermal analysis (DTA) of [MNP$\left.\mathrm{PIm}-\mathrm{SO}_{3} \mathrm{H}\right] \mathrm{Cl}$ as a worthy heterogeneous acidic MNPs catalyst shows the mass loss of organic material as they decompose upon heating (Figures 2 and 3). The major weight loss from the MNPs catalyst (room temperature to $110^{\circ} \mathrm{C}$ ) is due to the removal of physically adsorbed water and organic solvents, which were applied in the catalyst preparing. The weight loss is about $3 \%$. The weight loss $\left(7 \%\right.$ ) between 110 and $400{ }^{\circ} \mathrm{C}$ is linked mainly to the thermal decomposition imidazole functionalized via chlorosulfonic acid on the surface of silica-coated. [MNP-PIm$\left.\mathrm{SO}_{3} \mathrm{H}\right] \mathrm{Cl}$ shows three-step weight loss behavior. Weight loss of MNPs catalyst seems about $2 \%$ at $510-550{ }^{\circ} \mathrm{C}$, which is contributed to the thermal decomposition of the MNPs catalyst. As a consequence, the thermal gravimetric analysis of the MNPs catalyst presented significant loss in three steps, and decomposed above $510{ }^{\circ} \mathrm{C}$.

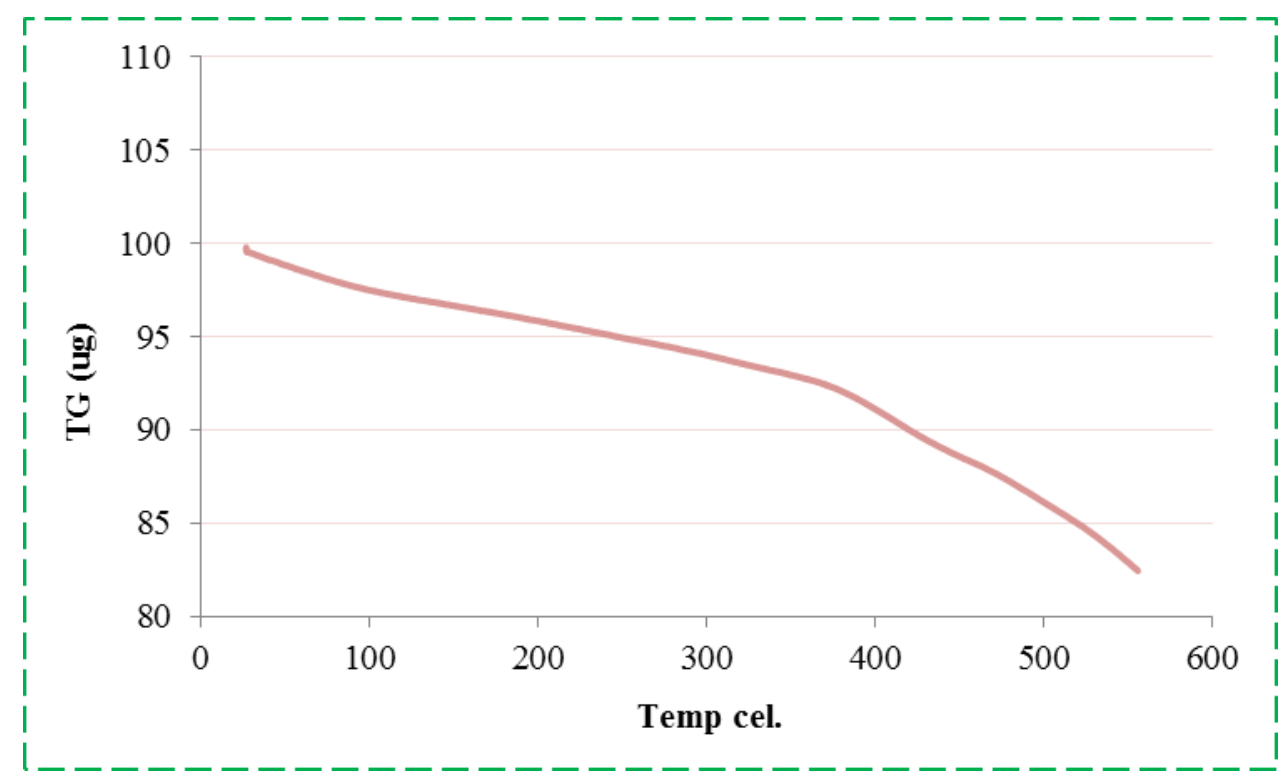

Fig. 2. The thermal gravimetric analysis (TGA) of $\left[\mathrm{MNP}-\mathrm{PIm}-\mathrm{SO}_{3} \mathrm{H}\right] \mathrm{Cl}$. 


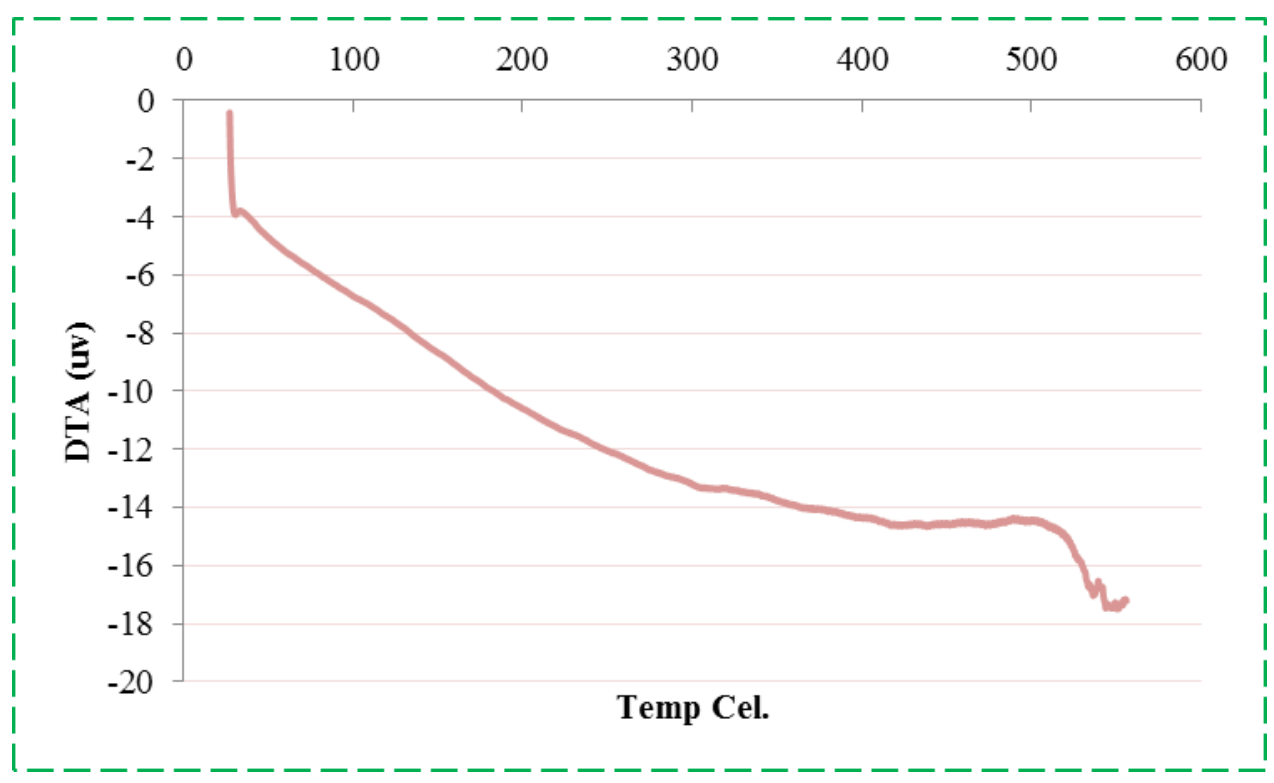

Fig. 3. The differential thermal analysis (DTA) of $\left[\mathrm{MNP}-\mathrm{PIm}-\mathrm{SO}_{3} \mathrm{H}\right] \mathrm{Cl}$.

Energy-dispersive X-ray spectroscopy (EDX) from the achieved [MNP-PIm-SO $\left.{ }_{3} \mathrm{H}\right] \mathrm{Cl}$ as a novel heterogeneous catalyst introduced the presence of the expected elements in the structure of the MNPs catalyst, for instance Fe, Si, O, N, S, C and Cl (Fig. 4).

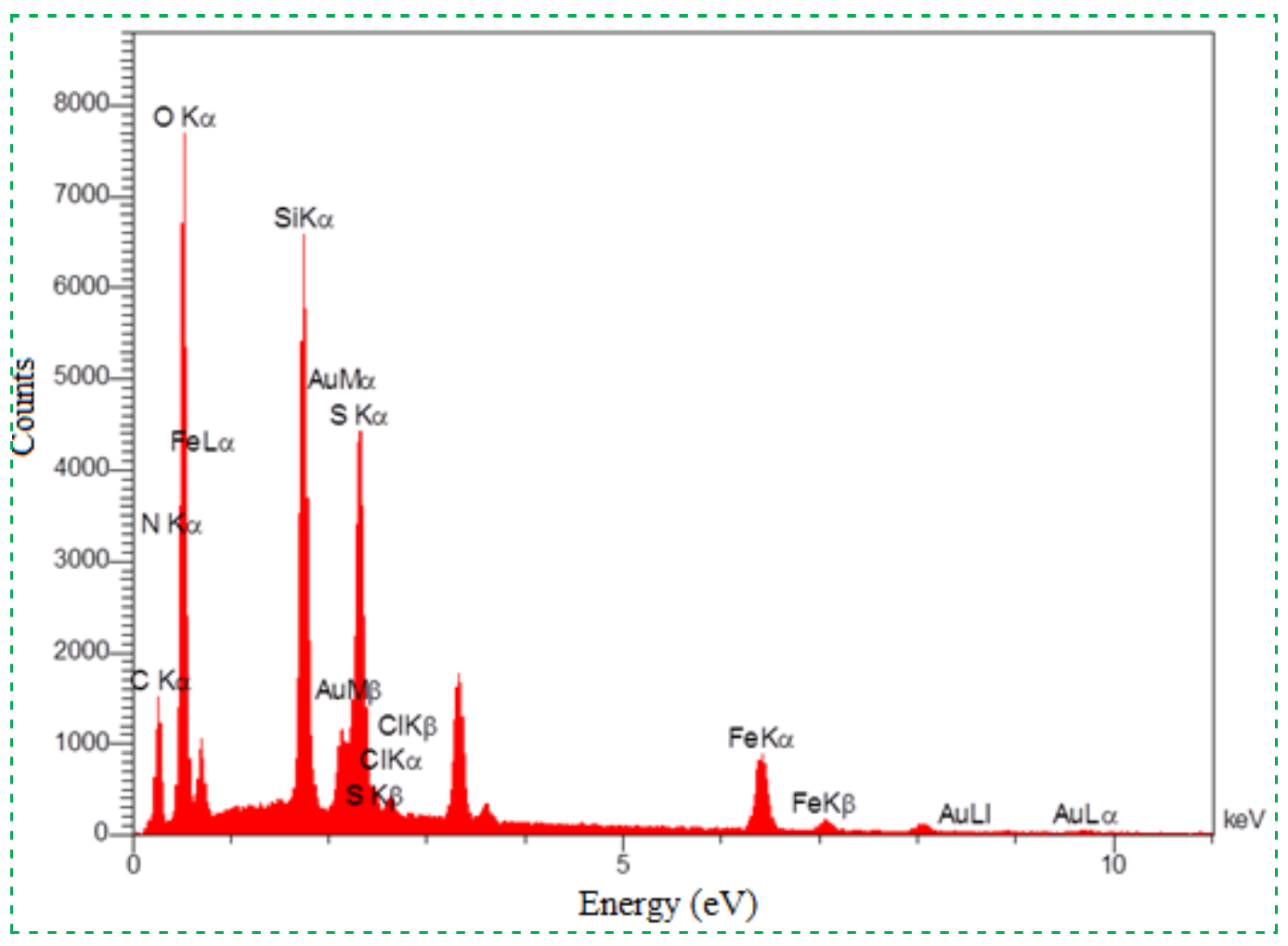


Fig. 4. The energy-dispersive X-ray spectroscopy (EDX) of $\left[\right.$ nano- $\mathrm{Fe}_{3} \mathrm{O}_{4} @ \mathrm{SiO}_{2} @\left(\mathrm{CH}_{2}\right)_{3}$-Imidazole- $\left.\mathrm{SO}_{3} \mathrm{H}\right] \mathrm{Cl}$ as a MNPs catalyst.

The size, shape and morphology of $\left[\mathrm{MNP}-\mathrm{PIm}-\mathrm{SO}_{3} \mathrm{H}\right] \mathrm{Cl}$ as a heterogeneous MNPs catalyst were studied by X-ray diffraction (XRD) pattern, scanning electron microscopy (SEM), transmission electron microscopy (TEM) and atomic force microscopy (AFM) analysis. The XRD pattern of the MNPs catalyst was considered in a range of 5-90 (Fig. 5). As exposed in Fig. 5, the XRD pattern displays diffraction lines of high crystalline nature at $2 \theta=12.90^{\circ}$, $20.40^{\circ}, 20.90^{\circ}, 24.60^{\circ}, 25.50^{\circ}, 26.00^{\circ}, 28.30^{\circ}, 30.80^{\circ}, 37.70^{\circ}$ and $81.70^{\circ}$. The peak width (FWHM), size and inter planar distance from the XRD pattern of $\left[\mathrm{MNP}-\mathrm{PIm}-\mathrm{SO}_{3} \mathrm{H}\right] \mathrm{Cl}$ were investigated in the $12.90^{\circ}$ to $81.70^{\circ}$ range and the achieved results are summarized in Table 1. For instance, assignments for the highest diffraction line, $20.90^{\circ}$, exposed an FWHM of 0.20 and a crystalline size for the catalyst of ca. $40.39 \mathrm{~nm}$ by the Debye-Scherrer's equation [D = $\mathrm{K} \lambda /(\beta \cos \theta)]$ (Where $\mathrm{D}$ is the crystalline size, $\mathrm{K}$ is the shape factor, being corresponding to $0.9, \lambda$ is the $\mathrm{X}$-ray wavelength, $\beta$ is the full width at half maximum of the diffraction peak, and $\theta$ is the Bragg diffraction angle in degree). An inter planar distance of $0.424530 \mathrm{~nm}$ (using the highest diffraction line at $\left.20.90^{\circ}\right)$ was found via the Bragg equation: dhkl $=\lambda /(2 \sin \theta),(\lambda$ : Cu radiation $(0.154178 \mathrm{~nm})$ was achieved. Crystallite sizes achieved from several diffraction lines by the Debye-Scherrer's equation were found to be in the nanometer range $(12.42-57.12 \mathrm{~nm})$, which is mainly in a good accordance with the SEM and TEM (Fig. 6). 


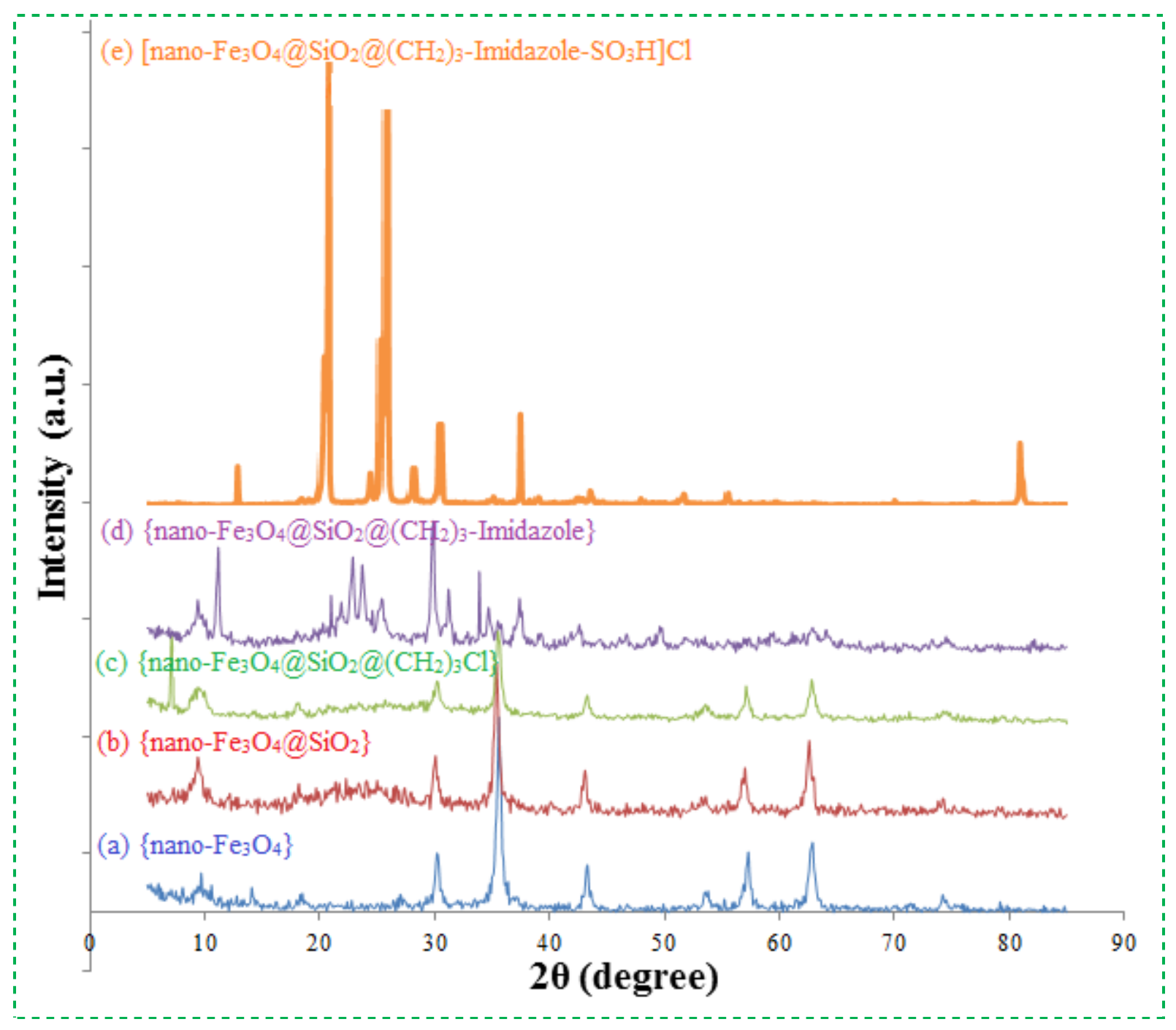

Fig. 5. The X-ray diffraction (XRD) pattern of $\left\{\right.$ nano- $\left.\mathrm{Fe}_{3} \mathrm{O}_{4}\right\}$ (a); $\left\{\right.$ nano- $\left.\mathrm{Fe}_{3} \mathrm{O}_{4} @ \mathrm{SiO}_{2}\right\}$ (b); $\{$ nano$\left.\mathrm{Fe}_{3} \mathrm{O}_{4} @ \mathrm{SiO}_{2} @\left(\mathrm{CH}_{2}\right)_{3} \mathrm{Cl}\right\}$ (c); $\left\{\right.$ nano- $\mathrm{Fe}_{3} \mathrm{O}_{4} @ \mathrm{SiO}_{2} @\left(\mathrm{CH}_{2}\right)_{3}$-Imidazole $\}$ (d); [nano- $\mathrm{Fe}_{3} \mathrm{O}_{4} @ \mathrm{SiO}_{2} @\left(\mathrm{CH}_{2}\right)_{3}-\mathrm{Imidazole}-$ $\left.\mathrm{SO}_{3} \mathrm{H}\right] \mathrm{Cl}(\mathrm{e})$ as a MNPs catalyst.

Table 1. X-ray diffraction (XRD) data for $\left[\right.$ nano- $\mathrm{Fe}_{3} \mathrm{O}_{4} @ \mathrm{SiO}_{2} @\left(\mathrm{CH}_{2}\right)_{3}$-Imidazole- $\left.\mathrm{SO}_{3} \mathrm{H}\right] \mathrm{Cl}$ as a MNPs catalyst.

\begin{tabular}{ccccc}
\hline \hline Entry & $2 \theta$ & Peak width [FWHM] (degree) & Size [nm] & Inter planer distance [nm] \\
\hline \hline 1 & 12.90 & 0.14 & 57.12 & 0.685444 \\
2 & 20.40 & 0.65 & 12.42 & 0.434819 \\
3 & 20.90 & 0.20 & 40.39 & 0.424530 \\
4 & 24.60 & 0.17 & 47.83 & 0.361451
\end{tabular}




\begin{tabular}{lllll}
5 & 25.50 & 0.60 & 13.58 & 0.348889 \\
6 & 26.00 & 0.20 & 40.77 & 0.342297 \\
7 & 28.30 & 0.22 & 37.24 & 0.314979 \\
8 & 30.80 & 0.28 & 29.44 & 0.289958 \\
9 & 37.70 & 0.18 & 46.64 & 0.288322 \\
10 & 81.70 & 0.19 & 25.93 & 0.117722 \\
\hline \hline
\end{tabular}
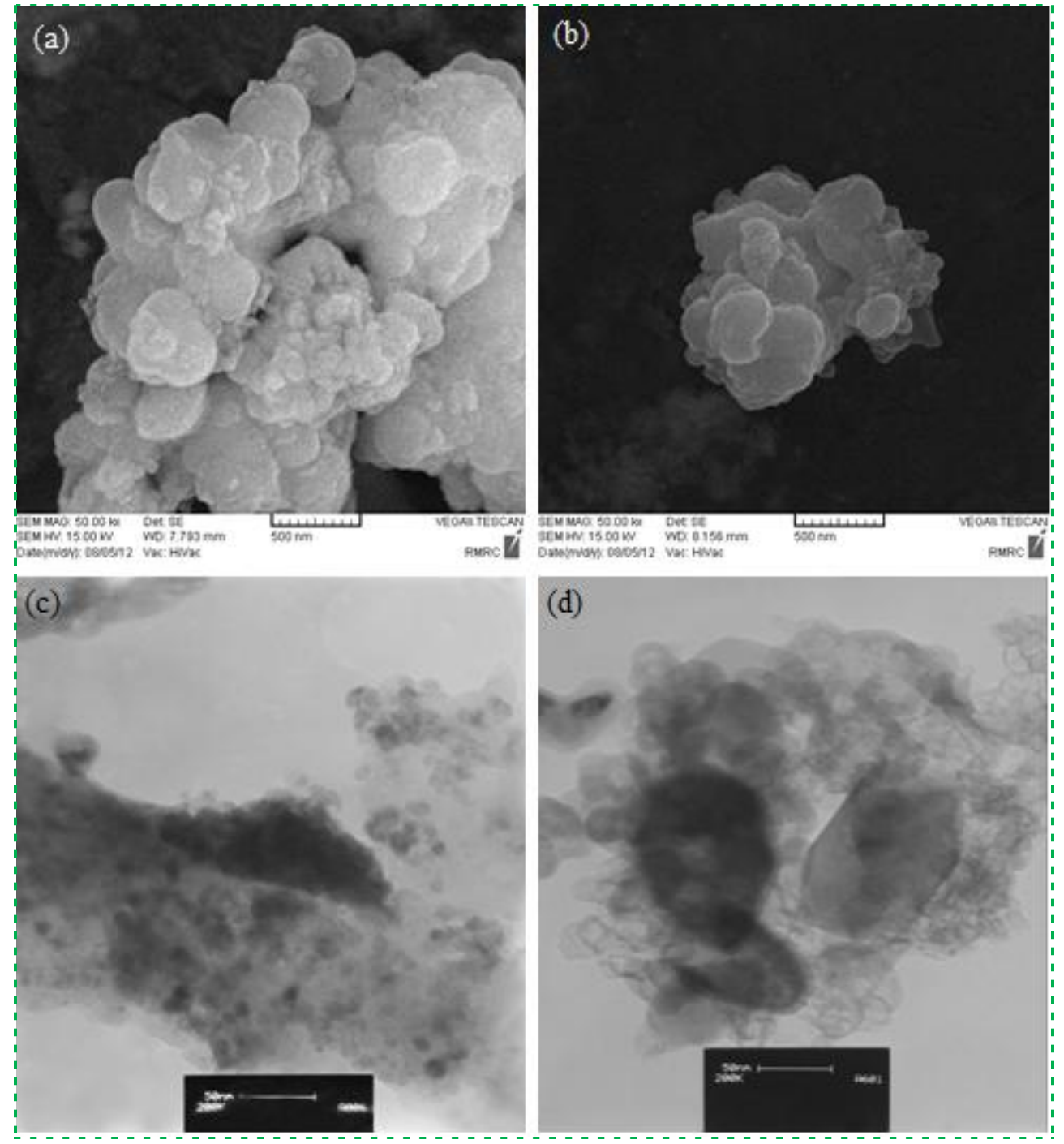

Fig. 6. The scanning electron microscopy (SEM) (a and b) and transmission electron microscopy (TEM) (c and d) of [nano- $\mathrm{Fe}_{3} \mathrm{O}_{4} @ \mathrm{SiO}_{2} @\left(\mathrm{CH}_{2}\right)_{3}$-Imidazole- $\left.\mathrm{SO}_{3} \mathrm{H}\right] \mathrm{Cl}$ as a MNPs catalyst. 
Atomic force microscopy (AFM) is a technique that lets us find and analyze surfaces with high resolution and accuracy. AFM gives numerous advantages; for instance hard surfaces like the surface of a ceramic material, or the dispersal of metallic nano composite; or very soft ones, such as molecules of proteins or plastic materials. Fig. 7 shows the two- and three-dimensional AFM images of [MNP-PIm-SO $\left.{ }_{3} \mathrm{H}\right] \mathrm{Cl}$ as a heterogeneous acidic MNPs catalyst. No important partition area in size is identified in the illustrations. By attaining the three-dimensional $2.1 \mu \mathrm{m}^{2}$ $\times 2.1 \mu \mathrm{m}^{2}$ frameworks, we can know that the achieved MNPs catalyst approves an interrupted structure with a desirable outside planarity. The surface of the coat on the MNPs catalyst was obviously exposed to be less than $60 \mathrm{~nm}$.

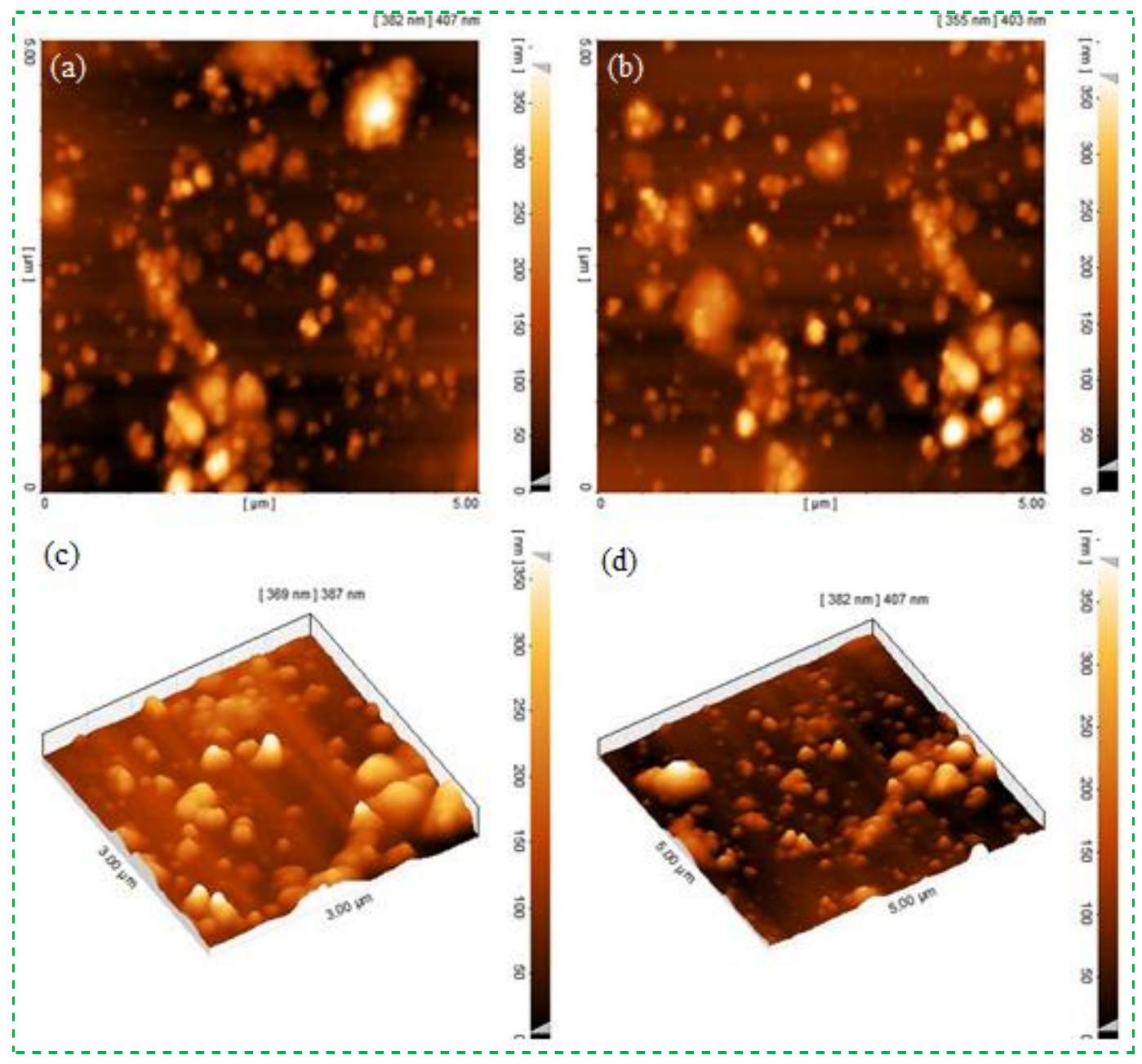


Fig. 7. A two- (a and b) and three-dimensional (c and d) atomic force microscopy (AFM) of [nano$\mathrm{Fe}_{3} \mathrm{O}_{4} @ \mathrm{SiO}_{2} @\left(\mathrm{CH}_{2}\right)_{3}$-Imidazole- $\left.\mathrm{SO}_{3} \mathrm{H}\right] \mathrm{Cl}$ as a MNPs catalyst.

\subsection{Application of [nano- $\mathrm{Fe}_{3} \mathrm{O}_{4} @ \mathrm{SiO}_{2} @\left(\mathrm{CH}_{2}\right)_{3}$-Imidazole-SO $\left.\mathrm{S}_{3} \mathrm{H}\right] \mathrm{Cl}$ as a MNPs catalyst in} the synthesis of 1,8-dioxo-octahydroxanthene derivatives.

At first, to optimize the reaction conditions, the condensation reaction between 4chlorobenzaldehyde and dimedone was chosen as a typical and different amounts of [MNP-PIm$\left.\mathrm{SO}_{3} \mathrm{H}\right] \mathrm{Cl}$ as a heterogeneous catalyst at range of room temperature upto $80{ }^{\circ} \mathrm{C}$ were studied under solvent-free conditions (Table 2). As showed in Table 2, the best results were achieved when the reaction was attained in the presence of $10 \mathrm{mg}$ of MNPs catalyst at $80{ }^{\circ} \mathrm{C}$ (Table 2, entry 8). No improvement was known in the yield of reaction by increasing the amount of the MNPs catalyst and temperature (Table 2, entries 9 and 10). Table 2 obviously exhibits that in the absence of MNPs catalyst, the product was not created (Table 2, entry 1). Furthermore, to compare the result of the solution in comparison with solvent-free conditions, a mixture of 4chlorobenzaldehyde and dimedone as a model reaction, by $10 \mathrm{mg}$ of MNPs catalyst in different solvents for instance water, $\mathrm{C}_{2} \mathrm{H}_{5} \mathrm{OH}, \mathrm{CH}_{3} \mathrm{CN}, \mathrm{CH}_{3} \mathrm{CO}_{2} \mathrm{Et}$, benzene and toluene was investigated at $80{ }^{\circ} \mathrm{C}$. Solvent-free condition was the foremost condition in this reaction. In Table 2 (entries 9 and 10) with regard to the reaction mechanism, it can be said that an increase in amount of catalyst protonate the carbonyl group of dimedone compound and the nucleophilic properties decrease. Therefore, the products are attained in lower yield.

Table 2. Result of amount of the catalyst and temperature in the synthesis of 1,8-dioxo-octahydroxanthene derivatives under solvent-free conditions. ${ }^{\text {a }}$

\begin{tabular}{ccccc}
\hline \hline Entry & Catalyst loading $(\mathrm{mg})$ & Reaction temperature $\left({ }^{\circ} \mathrm{C}\right)$ & Reaction time $(\mathrm{min})$ & Yield $(\%)$ \\
\hline \hline 1 & Catalyst-free & 80 & 120 & N.R \\
2 & 1 & 80 & 60 & 60
\end{tabular}




$\begin{array}{lllll}3 & 3 & 80 & 60 & 75 \\ 4 & 5 & 80 & 40 & 90 \\ 5 & 7 & 80 & 25 & 95 \\ 6 & 10 & \text { r.t. } & 180 & \text { N.R } \\ 7 & 10 & 60 & 60 & 70 \\ 8 & 10 & 80 & 15 & 98 \\ 9 & 15 & 80 & 15 & 97 \\ 10 & 20 & 80 & 10 & 97\end{array}$

"Reaction conditions: ${ }^{a}$ 4-Chlorobenzaldehyde (1 mmol), dimedone (2 mmol); ${ }^{b}$ Isolated yield.

After detecting the optimized reaction conditions, the investigation was followed by performing the reaction among aromatic aldehydes with dimedone. To display the overall applicability of this procedure, numerous aldehydes were capably reacted with two equivalents of dimedone under the same conditions. These results encouraged us to study the scope and the overview of this process for various aldehydes under optimized conditions. As showed in Table 3, a series of aromatic aldehydes underwent electrophilic substitution reaction with dimedone to afford a different series of substituted 1,8-dioxo-octahydroxanthene in high to superb yields. The nature and electronic properties of the substituents on the aromatic ring affect the conversion rate, and aromatic aldehydes having electron-withdrawing groups on the aromatic ring react faster than electron-donating groups do.

Table 3. The synthesis of 1,8-dioxo-octahydroxanthene derivatives in the presence of $0.01 \mathrm{~g}$ of of [nano$\mathrm{Fe}_{3} \mathrm{O}_{4} @ \mathrm{SiO}_{2} @\left(\mathrm{CH}_{2}\right)_{3}$-Imidazole- $\left.\mathrm{SO}_{3} \mathrm{H}\right] \mathrm{Cl}$ as a MNPs catalyst under solvent-free conditions at $80{ }^{\circ} \mathrm{C} .{ }^{\mathrm{a}}$

\begin{tabular}{ccccc}
\hline \hline Entry & Aldehyde & Time (min) & Yield $^{\mathrm{b}}(\%)$ & M.p $\left({ }^{\circ} \mathrm{C}\right)(\mathrm{Lit})[\mathrm{Ref}]$. \\
\hline \hline 1 & Benzaldehyde & 25 & 92 & 205-206 (203-205) [51a] \\
2 & 2-Nitrobenzaldehyde & 20 & 93 & 204-205 (203-205) [51a] \\
3 & 3-Nitrobenzaldehyde & 20 & 94 & $170-172(170-171)[51 \mathrm{~b}]$
\end{tabular}




\begin{tabular}{|c|c|c|c|c|}
\hline 4 & 4-Nitrobenzaldehyde & 15 & 96 & $226-228(224-226)[51 \mathrm{c}]$ \\
\hline 5 & 4-Chlorobenzaldehyde & 15 & 98 & $238-240(233-235)$ [51a] \\
\hline 6 & 3-Chlorobenzaldehyde & 20 & 95 & $185-187(185-187)[51 b]$ \\
\hline 7 & 2-Chlorobenzaldehyde & 20 & 96 & $226-227(225-227)[51 a]$ \\
\hline 8 & 2,4-Dichlorobenzaldehyde & 10 & 95 & $251-252(254-255)[51 d]$ \\
\hline 9 & 4-Fluorobenzaldehyde & 10 & 94 & $233-234(235-236)[51 e]$ \\
\hline 10 & 3-Fluorobenzaldehyde & 15 & 90 & $227-229(231-232)[51 f]$ \\
\hline 11 & 4-Bromobenzaldehyde & 10 & 97 & $239-241(241-243)[51 \mathrm{~g}]$ \\
\hline 12 & 2-Bromobenzaldehyde & 20 & 95 & $226-228(221-223)[51 \mathrm{~g}]$ \\
\hline 13 & 4-Methylbenzaldehyde & 40 & 91 & $210-211(210-213)[51 \mathrm{~h}]$ \\
\hline 14 & 4-Methoxybenzaldehyde & 40 & 89 & $249-251(257-258)[51 \mathrm{~h}]$ \\
\hline 15 & Naphthalene-2-carbaldehyde & 20 & 96 & $216-217(234-235)[51 f]$ \\
\hline 16 & Naphthalene-1-carbaldehyde & 20 & 92 & $237-238(236-238)[51 \mathrm{i}]$ \\
\hline 17 & 4- $N, N$-Dimethylaminobenzaldehyde & 30 & 89 & $223-225(224-226)[51 \mathrm{j}]$ \\
\hline 18 & 2-Hydroxy-3,5-dichlorobenzaldehyde & 20 & 94 & $230-232$ \\
\hline
\end{tabular}

Reaction conditions: ${ }^{a}$ Aldehyde (1 mmol), dimedone (2 mmol); ${ }^{b}$ Isolated yield.

In a probable mechanism (Scheme 3) [51], initially, aldehyde (2) is activated using the MNPs catalyst to provide 7. At that time, dimedone (1) attacks to the carbonyl group of the activated aldehyde (7), and gives intermediate (8). Subsequently, through removing one water molecule from (8), intermediate (9) is prepared. Reaction is followed via activation of intermediate (9) to provide (10) as a Michael acceptor. Then, Michael addition of dimedone (1) to intermediate (9) affords (10). Intermediate (10) converts to (11) via tautomerization. Finally, 1,8-dioxo-octahydroxanthene will be produced by eliminating one water molecule from (11). 


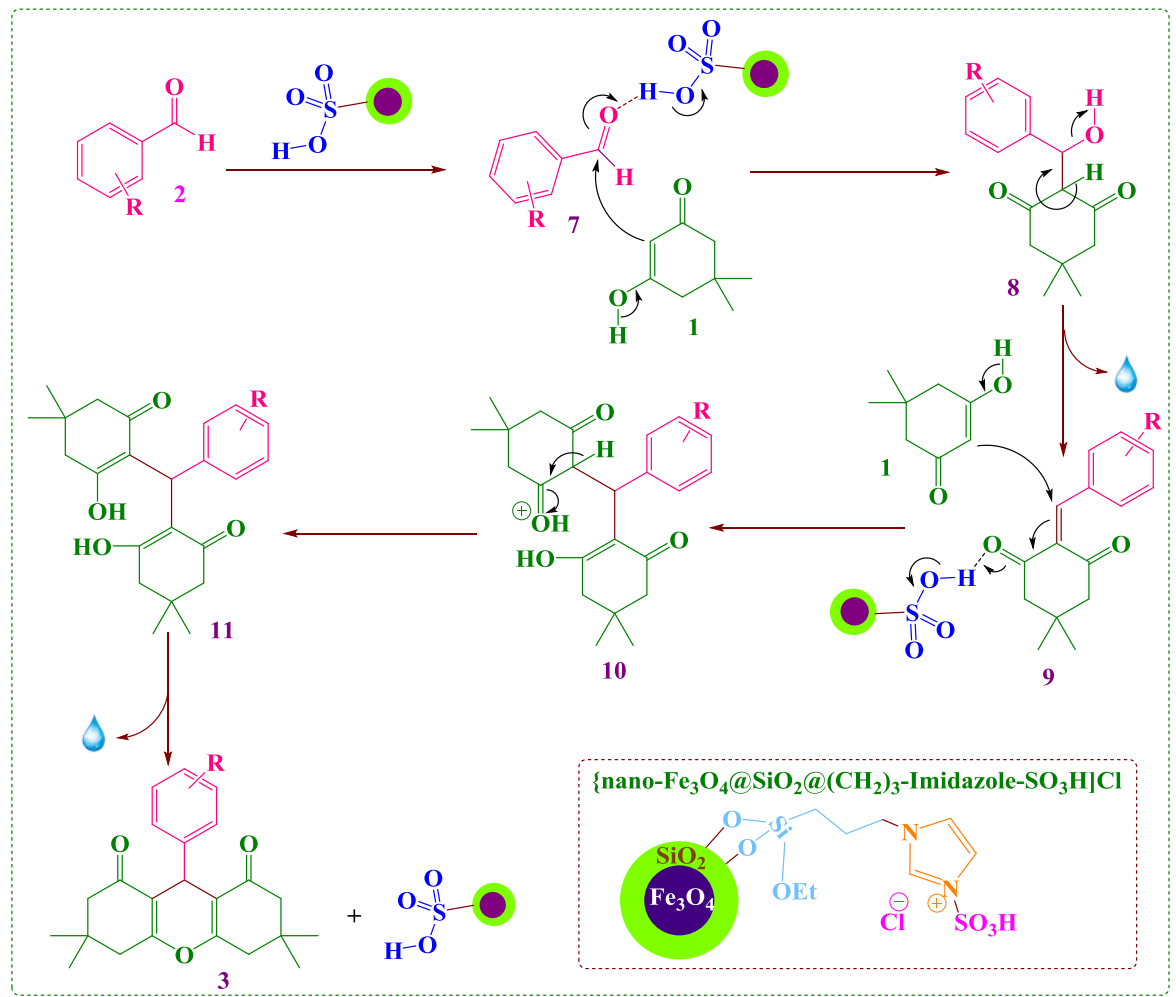

Scheme 3. The plausible mechanism for the synthesis of 1,8-dioxo-octahydroxanthene derivatives in the presence of [nano- $\mathrm{Fe}_{3} \mathrm{O}_{4} @ \mathrm{SiO}_{2} @\left(\mathrm{CH}_{2}\right)_{3}$-Imidazole- $\left.\mathrm{SO}_{3} \mathrm{H}\right] \mathrm{Cl}$ as a MNPs catalyst.

Furthermore, from the magnetic separation and isolation of the MNPs catalyst on reaction completion (the reaction between 4-chlorobenzaldehyde and dimedone), the additional probability to reuse and recycle the MNPs catalyst for several runs was also studied. Results displayed in Fig. 8 approve that the magnetically separable $\left[\mathrm{MNP}-\mathrm{PIm}-\mathrm{SO}_{3} \mathrm{H}\right] \mathrm{Cl}$ as a MNPs catalyst could be reused and recycled six runs without any remarkable loss of its first catalytic activity. The deactivation of the MNPs catalyst is low. The reaction was scaled up to $10 \mathrm{mmol}$ of 4-chlorobenzaldehyde and dimedone by $0.1 \mathrm{~g}$ of MNPs catalyst at $80{ }^{\circ} \mathrm{C}$. The yield of the reaction was $98 \%$ after 15 minutes and $93 \%$ after the sixth run. The results are summarized in Fig. 8. 


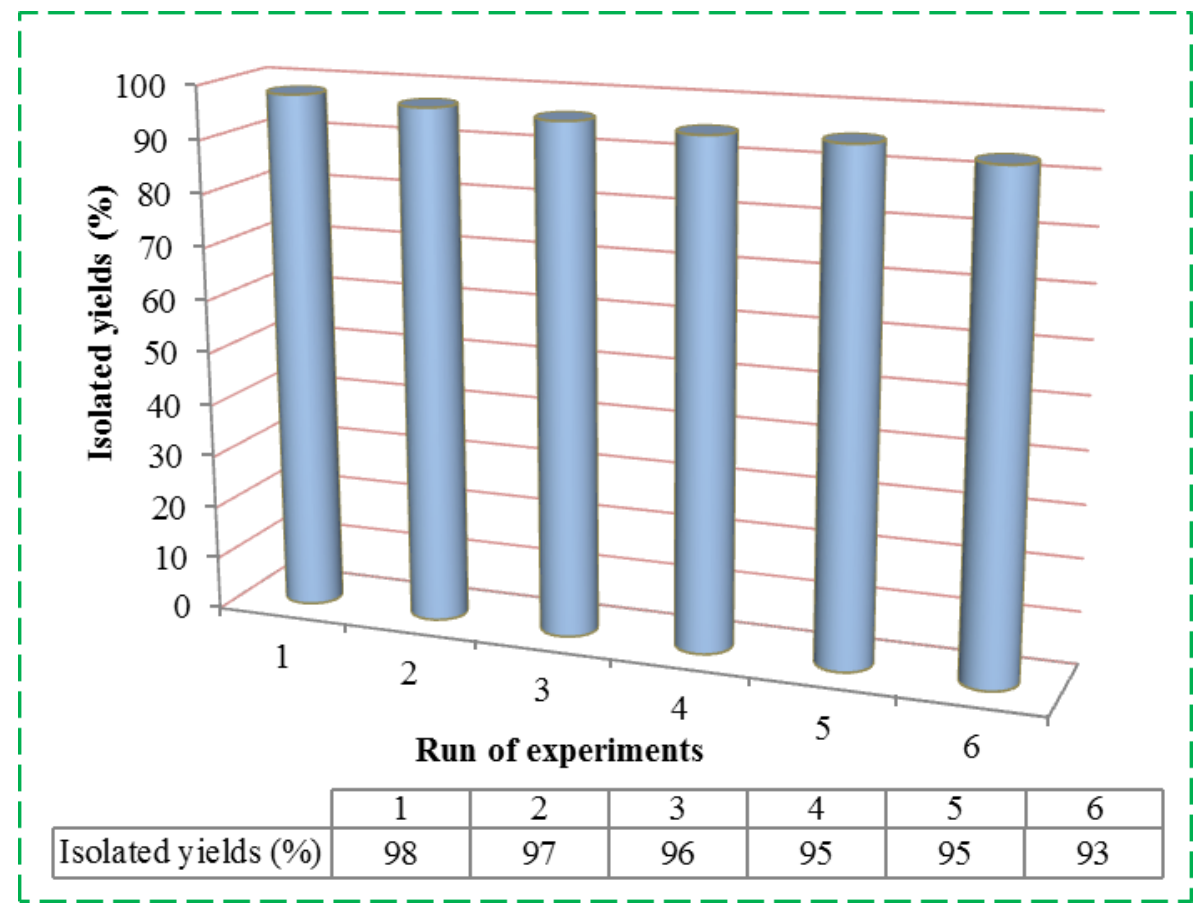

Fig. 8. Reusability of the $\left[\right.$ nano- $\left.\mathrm{Fe}_{3} \mathrm{O}_{4} @ \mathrm{SiO}_{2} @\left(\mathrm{CH}_{2}\right)_{3}-\mathrm{Imidazole}-\mathrm{SO}_{3} \mathrm{H}\right] \mathrm{Cl}$ as a MNPs catalyst on the synthesis of 1,8-dioxo-octahydroxanthene in 15 minutes.

3.3. Application of [nano- $\mathrm{Fe}_{3} \mathrm{O}_{4} @ \mathrm{SiO}_{2} @\left(\mathrm{CH}_{2}\right)_{3}$-Imidazole-SO 33$] \mathrm{Hl}$ as a MNPs catalyst in the synthesis of dihydropyrano[2,3-c]pyrazole derivatives.

In another study, to optimize the reaction conditions, the condensation reaction of 4chlorobenzaldehyde with malononitrile and 3-methyl-1-phenyl-2-pyrazoline-5-one was selected as a typical and different amounts of MNPs catalyst at range of room temperature up to $70{ }^{\circ} \mathrm{C}$ were confirmed under solvent-free conditions (Table 4). As displayed in Table 4, the best results were attained when the reaction was achieved using $7 \mathrm{mg}$ of MNPs catalyst at room temperature (Table 4, entry 5). No improvement was detected in the yield of reaction by increasing the amount of the MNPs catalyst and temperature (Table 4, entries 6-8). Table 4 clearly presents that in the absence of MNPs catalyst, the product was not produced (Table 4, entry 1). To compare the result of the solution with solvent-free conditions, a mixture of 4-chlorobenzaldehyde, malononitrile and 3-methyl-1-phenyl-2-pyrazoline-5-one as a model reaction, using $7 \mathrm{mg}$ of 
MNPs catalyst in various solvents for instance water, $\mathrm{CH}_{3} \mathrm{CN}, \mathrm{C}_{2} \mathrm{H}_{5} \mathrm{OH}, \mathrm{CH}_{3} \mathrm{CO}_{2} \mathrm{Et}$ and toluene was considered at room temperature. Solvent-free condition was the best condition in this reaction.

Table 4. Result of amount of the catalyst and temperature in the synthesis of dihydropyrano[2,3-c]pyrazole derivatives under solvent-free conditions. ${ }^{\mathrm{a}}$

\begin{tabular}{ccccc}
\hline \hline Entry & Catalyst loading $(\mathrm{mg})$ & Reaction temperature $\left({ }^{\circ} \mathrm{C}\right)$ & Reaction time $(\mathrm{min})$ & Yield $^{\mathrm{b}}(\%)$ \\
\hline \hline 1 & Catalyst-free & r.t. & 180 & N.R \\
2 & 1 & r.t. & 60 & 80 \\
3 & 3 & r.t. & 45 & 90 \\
4 & 5 & r.t. & 30 & 94 \\
5 & 7 & r.t. & 20 & 98 \\
6 & 10 & r.t. & 20 & 98 \\
7 & 7 & 50 & 20 & 98 \\
8 & 7 & 70 & 20 & 98 \\
\hline \hline
\end{tabular}

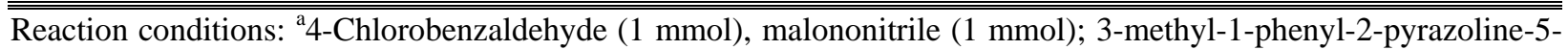
one (1 mmol); ${ }^{b}$ Isolated yield.

After optimization of the reaction conditions, to investigate the efficiency and the scope of the showed procedure, numerous dihydropyrano[2,3-c]pyrazole derivatives were produced by the one-pot three-component condensation reaction between aromatic aldehydes with malononitrile and 3-methyl-1-phenyl-2-pyrazoline-5-one using catalytic amounts of [MNP-PIm$\left.\mathrm{SO}_{3} \mathrm{H}\right] \mathrm{Cl}$ as an acidic MNPs catalyst under solvent-free reaction conditions. The results are displayed in Table 5. The effect of substituents on the aromatic ring was assessed strong in terms of yields under these reaction conditions. Both categories of aromatic aldehydes counting electron-releasing and electron-withdrawing substituents on their aromatic ring gained the appropriate products in high to excellent yields in short reaction time. The reaction time of 
aromatic aldehydes having electron withdrawing groups was rather faster than that of electron donating groups. Moreover, recyclability and reusability of the catalyst was also considered on the condensation of 4-chlorobenzaldehyde with malononitrile and 3-methyl-1-phenyl-2pyrazoline-5-one. Similarly, MNPs catalyst was separated and reused for alternative reaction.

Table 5. The synthesis of dihydropyrano[2,3-c]pyrazole derivatives using $7 \mathrm{mg}$ of $\left[\right.$ nano- $-\mathrm{Fe}_{3} \mathrm{O}_{4} @ \mathrm{SiO}_{2} @\left(\mathrm{CH}_{2}\right)_{3}-$ Imidazole- $\left.\mathrm{SO}_{3} \mathrm{H}\right] \mathrm{Cl}$ as a MNPs catalyst under solvent-free conditions at room temperature. ${ }^{\mathrm{a}}$

\begin{tabular}{|c|c|c|c|c|}
\hline Entry & Aldehyde & Time $(\min )$ & Yield $^{\mathrm{b}}(\%)$ & M.p $\left({ }^{\circ} \mathrm{C}\right)($ Lit) [Ref.] \\
\hline 1 & Benzaldehyde & 30 & 91 & 176-177 (169-171) [52a] \\
\hline 2 & 3-Nitrobenzaldehyde & 20 & 95 & $197-199(189-191)$ [52b] \\
\hline 3 & 4-Nitrobenzaldehyde & 15 & 97 & 197-198 (197-198) [52b] \\
\hline 4 & 4-Chlorobenzaldehyde & 20 & 98 & $186-187(175-178)$ [52a] \\
\hline 5 & 2-Chlorobenzaldehyde & 30 & 93 & $141-142(140-142)$ [52a] \\
\hline 6 & 2,4-Dichlorobenzaldehyde & 15 & 97 & $176-178(169-171)$ [52a] \\
\hline 7 & Naphthalene-2-carbaldehyde & 60 & 92 & $210-212(206-208)[45 b]$ \\
\hline 8 & 3-Bromobenzaldehyde & 30 & 96 & $163-165(169-170)[52 c]$ \\
\hline 9 & 4-Methylbenzaldehyde & 45 & 94 & $173-175(170-171)$ [52b] \\
\hline 10 & 4-Methoxybenzaldehyde & 60 & 92 & $176-178(174-176)[52 c]$ \\
\hline 11 & 4-Hydroxy-3-ethoxybenzaldehyde & 45 & 89 & $193-195(187-189)[52 d]$ \\
\hline 12 & Pyridine-4-carbaldehyde & 30 & 90 & $207-208(205)[52 \mathrm{e}]$ \\
\hline 13 & Naphthalene-1-carbaldehyde & 60 & 93 & $244-245(235-237)[45 b]$ \\
\hline 14 & Thiophen-2-carbaldehyde & 30 & 91 & $167-168(168-169)[52 f]$ \\
\hline 15 & 4-Hydroxybenzaldehyde & 70 & 89 & $208-210(213-215)[52 f]$ \\
\hline 16 & 2-Hydroxy-3,5-dichlorobenzaldehyde & 20 & 93 & $223-224$ \\
\hline 17 & Terephthalaldehyde & 90 & 85 & $240-242(235-236)[52 d]$ \\
\hline 18 & 2-Hydroxy-3-methoxybenzaldehyde & 60 & 85 & $301-303(297-299)[45 b]$ \\
\hline
\end{tabular}

Reaction conditions: ${ }^{a}$ Aldehyde $(1 \mathrm{mmol})$, malononitrile $(1 \mathrm{mmol})$; 3-methyl-1-phenyl-2-pyrazoline-5-one (1

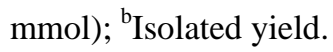


The suggested catalytic processes mentioned in Scheme 4 [52], are in accordance with literature studies [40, 41]. Initially arylidene malononitrile (14) was formed in quantitative yield by the Knoevenagel addition of activated malononitrile (4) to the activated aromatic aldehyde (7) through loss of one water molecule. The creation of the dihydropyrano-[2,3-c]-pyrazole (6) is proposed to contain the following tandem reactions: pyrazolone (13) creation after tautomerization of 3-methyl-1-phenyl-2-pyrazoline-5-one (5), Michael addition of pyrazolone (13) to arylidene malononitrile (14), followed by cyclization and tautomerization.

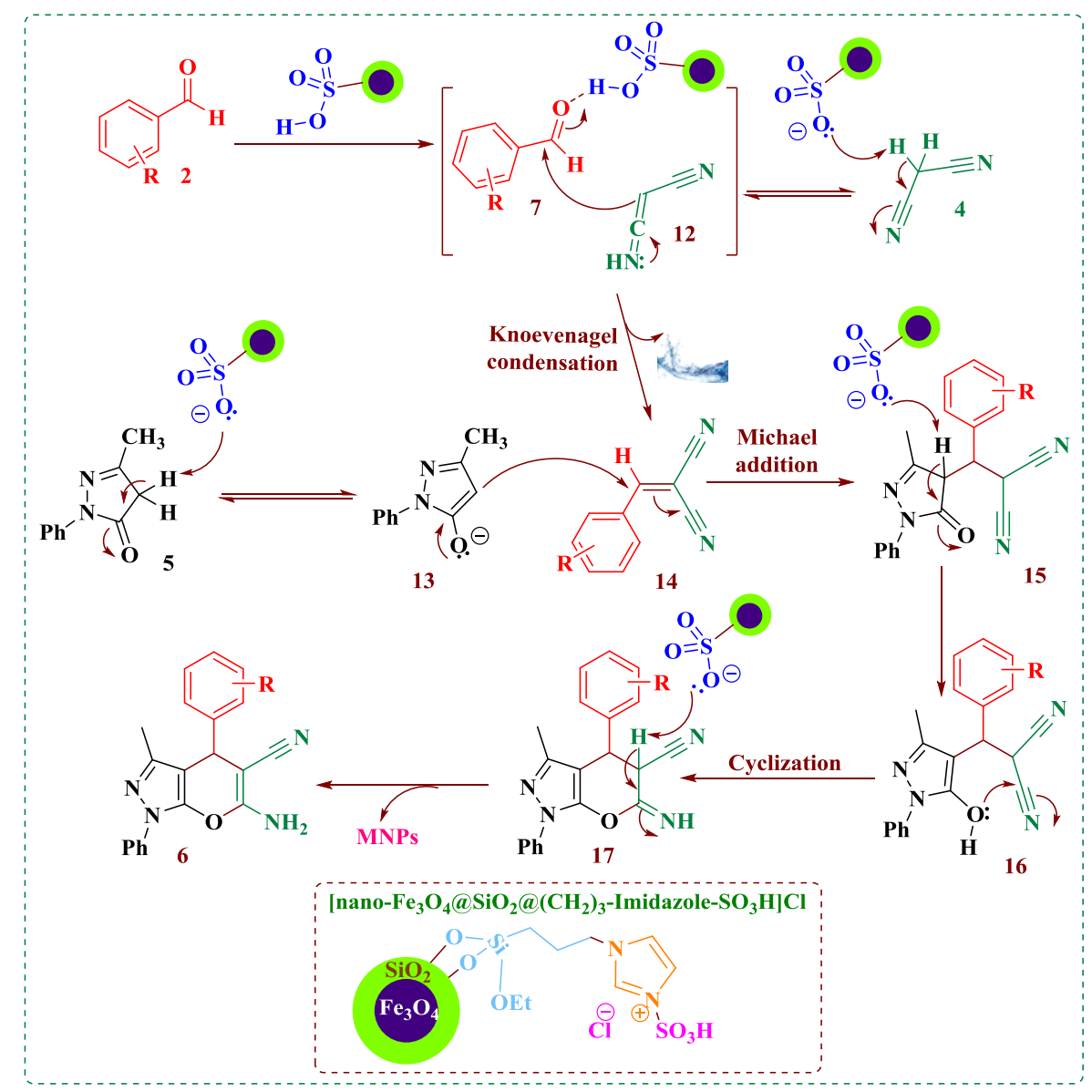

Scheme 4. The probable mechanism for the synthesis of dihydropyrano-[2,3-c]-pyrazole derivatives using [nano$\mathrm{Fe}_{3} \mathrm{O}_{4} @ \mathrm{SiO}_{2} @\left(\mathrm{CH}_{2}\right)_{3}$-Imidazole- $\left.\mathrm{SO}_{3} \mathrm{H}\right] \mathrm{Cl}$ as a MNPs catalyst.

Also, from the magnetic separation and isolation of the MNPs catalyst on reaction completion (the reaction between 4-chlorobenzaldehyde, malononitrile and 3-methyl-1-phenyl-2- 
pyrazoline-5-one), the additional possibility to reuse and recycle the MNPs catalyst for various runs was too investigated. Results showed in Fig. 9 cofirm that the magnetically separable MNPs catalyst could be reused and recycled six runs without any significant loss of its first catalytic activity. The deactivation of the MNPs catalyst is low. The reaction was scaled up to $10 \mathrm{mmol}$ of reactants by $0.07 \mathrm{~g}$ of MNPs catalyst at room temperature. The yield of the reaction was $98 \%$ after 20 minutes and $91 \%$ after the sixth run. The results are summarized in Fig. 9.

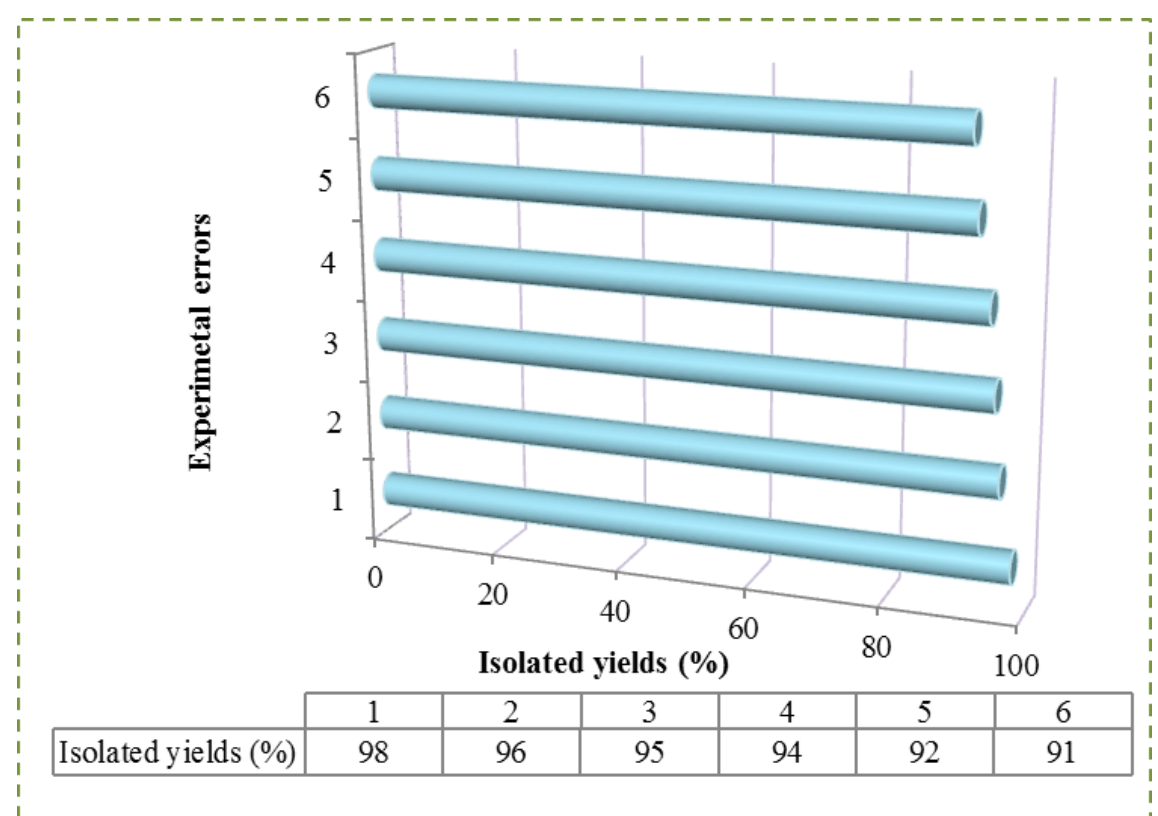

Fig. 9. Reusability of the $\left[\right.$ nano- $\mathrm{Fe}_{3} \mathrm{O}_{4} @ \mathrm{SiO}_{2} @\left(\mathrm{CH}_{2}\right)_{3}$-Imidazole- $\left.\mathrm{SO}_{3} \mathrm{H}\right] \mathrm{Cl}$ as a MNPs catalyst on the synthesis of dihydropyrano-[2,3-c]-pyrazole in 20 minutes.

$\mathrm{N}_{2}$ adsorption-desorption measurements were studied to investigate the Brunauer-EmmettTeller (BET) analysis specific surface area of the materials (Fig. 10, I). The BET surface area of MNPs catalyst is $128.2 \mathrm{~m}^{2} / \mathrm{g}$ (total pore volume $=0.281 \mathrm{~cm}^{3} \mathrm{~g}^{-1}$; mean pore diameter $=8.77 \mathrm{~nm}$ ) and its pore size distribution to plotted in Fig. 10, II. The obtained surface area for $\mathrm{Fe}_{3} \mathrm{O}_{4} \mathrm{NPs}_{\mathrm{s}}$ is $34.2 \mathrm{~m}^{2} / \mathrm{g}$ (total pore volume $=0.159 \mathrm{~cm}^{3} \mathrm{~g}^{-1} ;$ mean pore diameter $=18.56 \mathrm{~nm}$ ) and its pore size distribution to plotted in Fig. 10, II. In comparison to $\mathrm{Fe}_{3} \mathrm{O}_{4}$ NPs the BET surface area of the MNPs catalyst increased. Specific surface area in MNPs catalyst increases due to coating of 
$\mathrm{Fe}_{3} \mathrm{O}_{4}$ NPs with grafting organic tags (Fig. 10, I and II ). The higher surface area of the prepared catalyst in comparison to $\mathrm{Fe}_{3} \mathrm{O}_{4} \mathrm{NPs}$ core can be considered as one of the advantages of this catalyst. The pore sizes of both samples are mainly between 1 to $10 \mathrm{~nm}$ which indicates that the samples contain both microspores and mesopores.

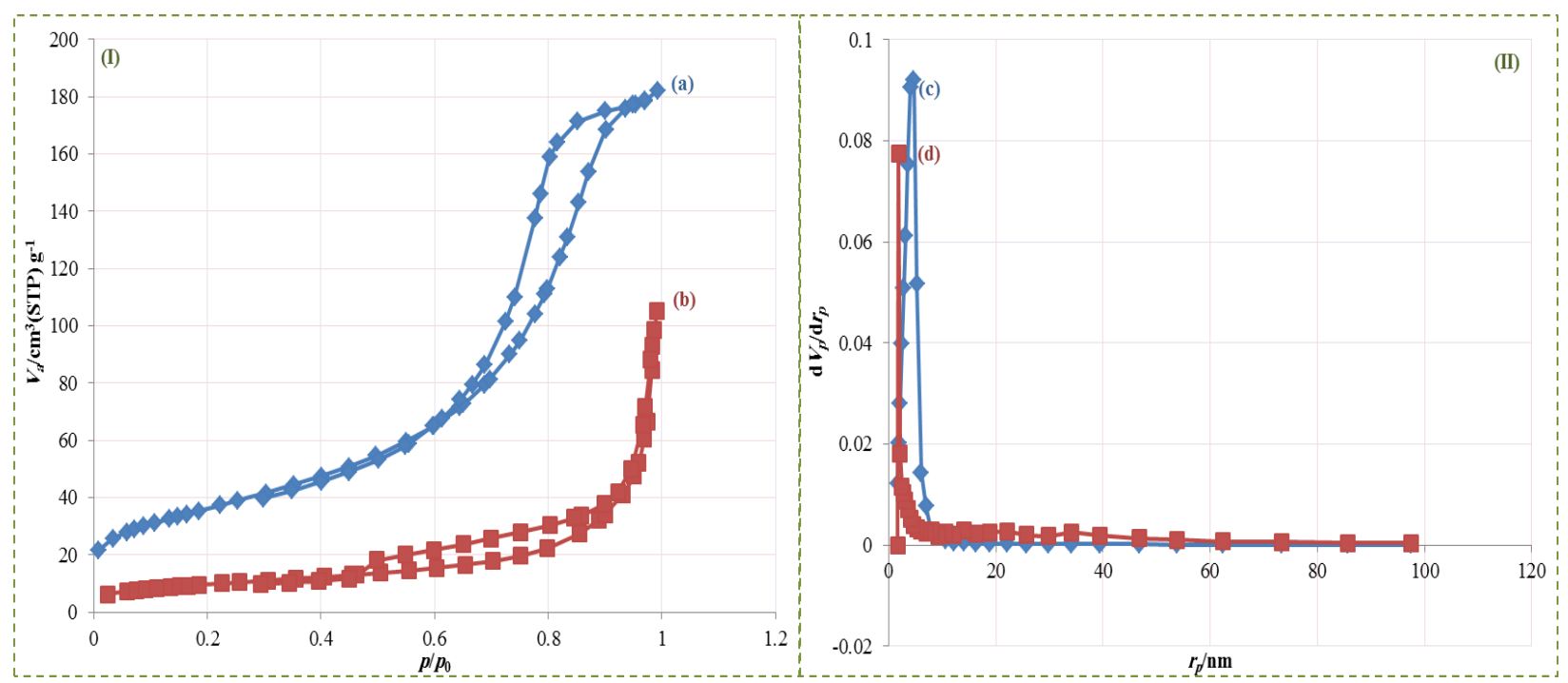

Fig. 10. $\mathrm{N}_{2}$ adsorption-desorption isotherms (BET) of $\mathrm{Fe}_{3} \mathrm{O}_{4} \mathrm{NPs}$ (a and c) and MNPs catalyst (b and d).

The general approaches to test for the presence or absence of leached soluble Fe in the reaction solution are a hot filtration test or elemental analysis of Fe in the solution. Finally, the full heterogeneous character of the catalytically active species as well as the recyclability and reusability of the MNPs catalyst were approved by hot-filtration test and via multiple reuses (six run) of the MNPs catalyst in further 1,8-dioxo-octahydroxanthene. A typical reaction between 4chlorobenzaldehyde and dimedone was carried out using $0.01 \mathrm{~g}$ under solvent-free conditions at $80{ }^{\circ} \mathrm{C}$. A hot filtration test is applied after 30-35\% conversion of 1,8-dioxo-octahydroxanthene had been attained to ensure that any leached soluble Fe in the filtrate would be enough to continue a homogeneous reaction after removing the MNPs catalyst. The results were sumarized in Fig. 11. 


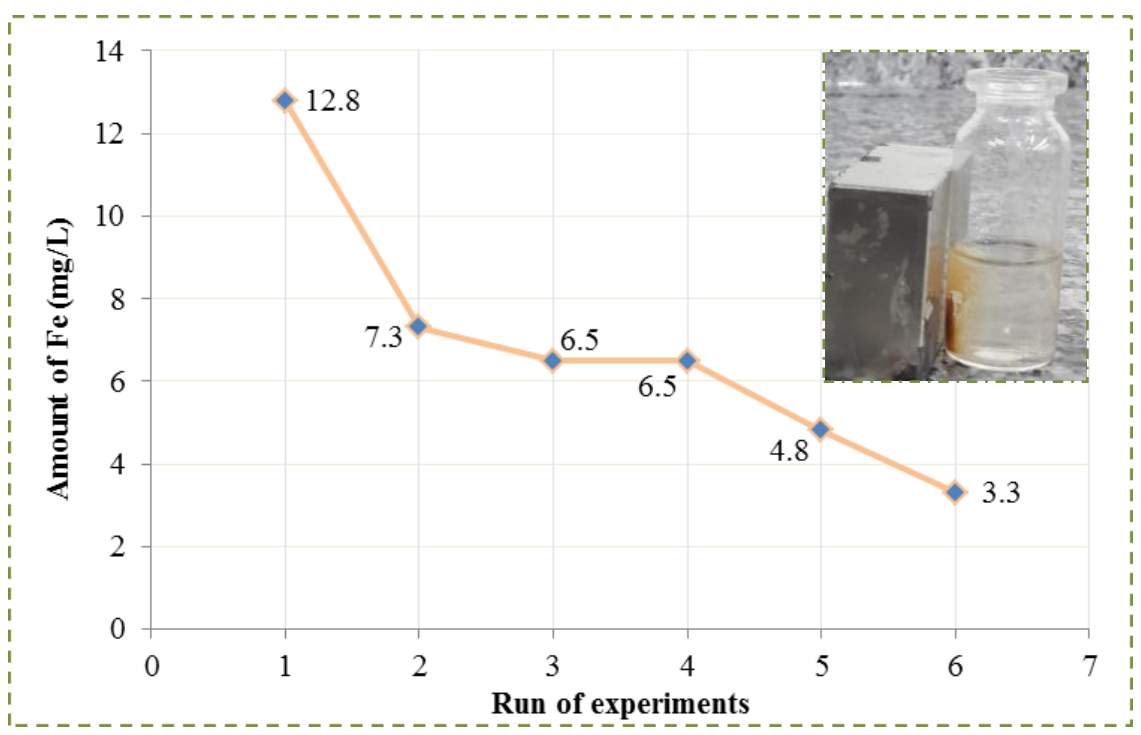

Fig. 11. The inductively coupled plasma (ICP) analysis via hot filtration test to determinate of Fe in the recycled MNPs catalyst.

To compare the efficacy of our catalyst with some reported catalysts for the synthesis of 1,8-dioxo-octahydroxanthenes and dihydropyrano[2,3-c]pyrazoles, we have presented the results of these catalysts to attain the condensation of 4-nitrobenzaldehyde and dimedone (in the synthesis of 1,8-dioxo-octahydroxanthene) or 4-chlorobenzaldehyde, malononitrile and 3methyl-1-phenyl-2-pyrazoline-5-one (in the synthesis of 1 dihydropyrano[2,3-c]pyrazoles) in Table 6. As Table 6 displays, MNPs catalyst has extraordinarily improved the synthesis of compounds in different terms (reaction time, yield and amount of catalyst).

Table 6. Comparison of the results our studies with reported works. ${ }^{a}$

\begin{tabular}{cccccc}
\hline \hline Entry & Reaction condition & Catalyst loading & Time (min) & Isolated yields (\%) & [Ref.] \\
\hline \hline 1 & DABCO-Br & $0.015 \mathrm{~g}$ & 150 & 83 & [53a] \\
2 & $\mathrm{SmCl}_{3}$ & $20 \mathrm{~mol} \%$ & 480 & 97 & {$[53 \mathrm{~b}]$} \\
3 & $\mathrm{TBAHS}$ & $10 \mathrm{~mol} \%$ & 210 & 94 & {$[53 \mathrm{c}]$} \\
4 & $10 \mathrm{~mol} \%$ & 180 & 95 & {$[53 \mathrm{~d}]$} \\
5 & EPZ 10 & $0.01 \mathrm{~g}$ & 15 & 96 & This work
\end{tabular}




\begin{tabular}{cccccc}
6 & {$[$ Sipim $] \mathrm{H}_{\mathrm{S}} \mathrm{O}_{4}$} & $0.1 \mathrm{~g}$ & 90 & 95 & [54a] \\
7 & $\mathrm{TEBA}$ & $0.15 \mathrm{~g}$ & 360 & 99 & [41] \\
8 & $\mathrm{PTSA}$ & $0.05 \mathrm{~g}$ & 50 & 95 & {$[54 \mathrm{~b}]$} \\
9 & $1 \mathrm{~mol} \%$ & 50 & 95 & {$[54 \mathrm{c}]$} \\
10 & $\mathrm{H}_{14}\left[\mathrm{NaP}_{5} \mathrm{~W}_{30} \mathrm{O}_{110}\right]$ & $0.007 \mathrm{~g}$ & 20 & 98 & This work \\
\hline \hline
\end{tabular}

\section{Conclusion}

In summary, a novel heterogeneous, recycle and reusable organosilica imidazole-based ionic liquid-stabilized on silica coated $\mathrm{Fe}_{3} \mathrm{O}_{4}$ magnetic nano particles [MNP-PIm- $\mathrm{SO}_{3} \mathrm{H}$ ]Cl was designed, produced and fully characterized by using FT-IR, thermo gravimetric analysis (TGA), differential thermal analysis (DTA), EDX, XRD, SEM, TEM, AFM, BET and ICP analysis. Catalytic applications of described catalyst was investigated in the synthesis of 1,8-dioxooctahydroxanthenes and dihydropyrano[2,3-c]pyrazole derivatives under mild and solvent-free conditions. Noteworthy advantages of this study are relatively simplicity of product isolation, cleaner reaction profile, eco-friendly benign, high yield, short reaction time, recycle and reusability of the $\left[\mathrm{MNP}-\mathrm{PIm}-\mathrm{SO}_{3} \mathrm{H}\right] \mathrm{Cl}$ catalyst.

\section{Acknowledgements}

We thank Bu-Ali Sina University and Iran National Science Foundation (INSF) for financial support (The Grant of Allameh Tabataba'i's Award, Grant Number: BN093) to our research group.

\section{References}

1. $\quad$ M.A. Zolfigol, R. Ayazi, S. Baghery, RSC Adv. 5 (2015) 71942-71954. 
2. O. Deutschmann, H.K. Ozinger, K. Kochloefl, T. Turek, Heterogeneous Catalysis and Solid Catalysts, Wiley-VCH Verlag GmbH \& Co. KGaA, Weinheim, (2009) doi: 10.1002/14356007.a05_313.pub2.

3. Y.C. Sharma, B. Singh, Biofuels, Bioprod, Bioref, 5 (2011) 69-92.

4. B. Karimi, F. Mansouri, H.M. Mirzaei, Chem. Cat. Chem. 7 (2015) 1736-1095.

5. A.H. Lu, E.L. Salabas, F. Schìth, Angew. Chem. Int. Ed. 46 (2007) 1222-1244; Angew. Chem. 119 (2007) 1242-1266.

6. S. Laurent, D. Forge, M. Port, A. Roch, C. Robic, L.V. Elst, R.N. Muller, Chem. Rev. 108 (2008) 2064-2110.

7. G.P. Ellis, The chemistry of heterocyclic compounds, In Chromene, Chromanes and Chromone, Edited by: A. Weissberger, Taylor ECE, John Wiley, New York, 2 (1977) 13.

8. J.P. Poupelin, G. Saint-Rut, O. Foussard-Blanpin, Eur. J. Med. Chem. 13 (1978) 67-71.

9. J.F. Callan, P. De Silva, D.C. Magri: Tetrahedron. 61 (2005) 8551-8588.

10. O. Sirkecioglu, N. Talinli, A. Akar, J. Chem. Res. (S). (1995) 502-506.

11. F.M. Abdel Galil, B.Y. Riad, S.M. Sherif, M.H. Elnagdi, Chem. Lett. (1982) 1123-1126.

12. E.A.A. Hafez, M.H. Elnagdi, A.G.A. Elagamey, F.M.A.A. El-Taweel, Heterocycles. 26 (1987) 903-907.

13. S. Hatakeyma, N. Ochi, H. Numata, S. Takano, J. Chem. Soc., Chem. Commun. (1988) 1202-1204.

14. A. Banerjee, A.K. Mukherjee, Stain Technol. 56 (1981) 83-85.

15. R.M. Ion, D. Frackowiak, A. Planner, K. Wiktorowicz, Acta. Biochim. Pol. 45 (1998) 833845.

16. G. Saint-Ruf, A. De, H.T. Hieu, Bull. Chim. Ther. 7 (1972) 83-86. 
17. G. Saint-Ruf, H.T. Hieu, J.P. Poupelin, Naturwissenschaften. 62 (1975) 584-585.

18. (a) D.W. Knight, P.B. Little, Synlett. 10 (1998) 1141-1143; (b) D.W. Knight, P.B. Little, J. Chem. Soc., Perkin. Trans. 14 (2001) 1771-1777.

19. A. Jha, J. Beal, Tetrahedron Lett. 45 (2004) 8999-9002.

20. D. Quintas, A. Garci, D. Bomiuguez, Chem. Inform 35 (2004) 154.

21. C.W. Kuo, J.M. Fang, Synth. Commun. 31 (2001) 877-892.

22. G. Casiraghi, G. Casnati, M. Cornia, Tetrahedron Lett. 14 (1973) 679-682.

23. P. Papini, R. Cimmarusti, Gazz. Chim. Ital. 77 (1947) 142-145.

24. K. Ota, T. Kito, Bull. Chem. Soc. Jpn. 49 (1976) 1167-1168.

25. N. Foloppe, L.M. Fisher, R. Howes, A. Potter, A.G.S. Robertson, A.E. Surgenor, Bioorg. Med. Chem. 14 (2006) 4792-4802.

26. M.E.A. Zaki, E.M. Morsy, M. Abdul, Heterocycl. Commun. 10 (2004) 97-102.

27. J.L. Wang, D. Liu, Z.J. Zheng, S. Shan, X. Han, S.M. Srinivasula, C.M. Croce, E.S. Alnemri, Z. Huang, Proc. Natl. Acad. Sci. U.S.A. 97 (2009) 7124-7129.

28. (a) M.E.A. Zaki, H.A. Saliman, O.A. Hickal, A.E.Z. Rashad, Naturforsch. C. Biosci. 61 (2006) 1-5; (b) C.K. Sheng, J.H. Li, N. Hideo, J. Med. Chem. 27 (1984) 539-544.

29. (a) W.P. Smith, L.S. Sollis, D.P. Howes, C.P. Cherry, D.I. Starkey, N.K. Cobley, J. Med. Chem. 41 (1998) 787-797; (b) K. Mazaahir, S. Shilpi, R.K. Khalilur, S.T. Sharanjit, Bioorg. Med. Chem. Lett. 15 (2005) 4295-4298.

30. (a) H. Junek, H. Aigner, Chem. Ber. 106 (1973) 914-921; (b) H. Wamhoff, E. Kroth, K. Strauch, Synthesis, 11 (1993) 1129-1132.

31. A.V. Stachulski, N.G. Berry, A.C.L. Low, S.L. Moores, E. Row, D.C. Warhurst, I.S. Adagu, J.F. Rossignol, J. Med. Chem. 49 (2006) 1450-1454. 
32. H.H. Otto, Arch. Pharm. 307 (1974) 444-447.

33. G. Vasuki, K. Kumaravel, Tetrahedron Lett. 49 (2008) 5636-5638.

34. S. Gogoi, C.G. Zhao, Tetrahedron Lett. 50 (2009) 2252-2255.

35. K. Kumari, D.S. Raghuvanshi, V. Jouikov, K.N. Singh, Tetrahedron Lett. 53 (2012) 11301133.

36. A.M. Shestopalov, Y.M. Emeliyanova, A.A. Shestopalov, L.A. Rodinovskaya, Z.I. Niazimbetova, D.H. Evans, Tetrahedron. 59 (2003) 7491-7496.

37. Y. Peng, G. Song, R. Dou, Green Chem. 8 (2006) 573-575.

38. A.M. Shestopalov, Y.M. Emeliyanova, A.A. Shestopalov, L.A. Rodinovskaya, Z.I. Niazimbetova, D.H. Evans, Org. Lett. 4 (2002) 423-425.

39. A. Siddekha, A. Nizam, M.A. Pasha, Spectrochem. Acta. A. 81 (2011) 431-440.

40. S. Maddila, S. Rana, R. Pagadala, Sh. Kankala, S. Maddila, S.B. Jonnalagadda, Catal. Commun. 61 (2015) 26-30.

41. D. Shi, J. Mou, Q. Zhuang, L. Niu, N. Wu, X. Wang, Synth. Commun. 34 (2004) 45574563.

42. See review: (a) P. Salehi, M.A. Zolfigol, F. Shirini, M. Baghbanzadeh, Curr. Org. Chem. 10 (2006) 2171-2189; (b) M. Daraei, M.A. Zolfigol, F. Derakhshan-Panah, M. Shiri, H.G. Kruger, M. Mokhlesi, J. Iran. Chem. Soc. 12 (2015) 855-861; (c) M. Safaiee, M. A. Zolfigol, M. Tavasoli, M. Mokhlesi, J. Iran. Chem. Soc. 11 (2014) 1593-1597.

43. See review: M.A. Zolfigol, F. Shirini, P. Salehi, M. Abedini, Curr. Org. Chem. 12 (2008) 183-202.

44. (a) M.A. Zolfigol, V. Khakyzadeh, A.R. Moosavi-Zare, A. Rostami, A. Zare, N. 
Iranpoor, M.H. Beyzavi, R. Luque, Green Chem. 15 (2013) 2132-2140; (b) M.A. Zolfigol, T. Azadbkht, V. Khakizadeh, R. Nejatyami, D. Perrin, RSC. Adv. 4 (2014) 40036-40042; (c) T. Azadbakht, M.A. Zolfigol, R. Azadbakht, V. Khakizadeh, D. Perrin, New J. Chem. 39 (2015) 439-444.

45. (a) M.A. Zolfigol, S. Baghery, A.R. Moosavi-Zare, S.M. Vahdat, J. Mol. Catal. A. Chem. 409 (2015) 216-226; (b) M.A. Zolfigol, F. Afsharnadery, S. Baghery, S. Salehzadeh, F. Maleki, RSC Adv. 5 (2015) 75555-75568; and our references cited therein.

46. (a) N. Koukabi, E. Kolvari, A. Khazaei, M.A. Zolfigol, B. Shirmardi-Shaghasemi, H.R. Khavasi, Chem. Commun. 47 (2011) 9230-9232; (b) S. Qu, H. Yang, D. Ren, S. Kan, G. Zou, D. Liand, M. Li, J. Colloid Interface Sci. 215 (1999) 190-192.

47. Y.H. Deng, C.C. Wang, J.H. Hu, W.L. Yang, S.K. Fu, Colloids Surf. A. 262 (2005) 87-93.

48. A. Chrobok, S. Baj, W. Pudło, A. Jarzebski, Appl. Catal. A. Gen. 366 (2009) 22-28.

49. (a) A. Taheri, X. Pan, C. Liu, Y. Gu, Chem. Sus. Chem. 7 (2014) 2094-2098; (b) A. Taheri, B. Lai, C. Cheng, Y. Gu, Green Chem. 17 (2015) 812-816; (c) A. Taheri, C. Liu, B. Lai, C. Cheng, X. Pan, Y. Gu, Green Chem. 16 (2014) 3715-3719.

50. (a) A.R. Moosavi-Zare, M.A. Zolfigol, M. Zarei, A. Zare, J. Afsar, Appl. Catal. A. Gen. 505 (2015) 224-234; (b) A.R. Moosavi-Zare, M.A. Zolfigol, M. Zarei, A. Zare, V. Khakyzadeh, J. Mol. Liq. 211 (2015) 373-380.

51. (a) B. Maleki, M. Gholizadeh, S. Zeinalabedin, Bull. Korean Chem. Soc. 32 (2011) 16971702; (b) F. Shirini, Gh.H. Imanzadeh, M. Abedini, M. Akberi Dokhte-Ghaziani, P. Ghods Ghasemabadi, M. Safarpoor Langroodi, Iran. J. Catal. 2 (2012) 115-119; (c) A. Khazaei, A.R. Moosavi-Zare, Z. Mohammadi, A. Zare, V. Khakyzadeh, Gh. Darvishi, RSC Adv. 3 (2013) 1323-1326; (d) S. Kantevari, R. Bantu, L. Nagarapu, Arkivoc, xvi (2006) 136-148; 
(e) F. Shirini, A. Yahyazadeh, K. Mohammadi, Chin. Chem. Lett. 25 (2014) 341-347; (f)

A. Amoozadeh, S. Rahmani, J. Mol. Catal. A. Chem., 396 (2014) 96-107; (g) A. Hasaninejad, M. Dadar, A. Zare, Chem. Sci. Trans. 1 (2012) 233-238; (h) H.R. Shaterian, A. Hosseinian, M. Ghashang, Turk. J. Chem. 33 (2009) 233-240; (i) H.R. Shaterian, A. Hosseinian, M. Ghashang, Phosphorus Sulfur Sili. Relat. Elem. 183 (2008) 3136-3144; (j) M. Maghsoodlou, S.M. Habibi-Khorassani, Z. Shahkarami, N. Maleki, M. Rostamizadeh, Chin. Chem. Lett., 21 (2010) 686-689.

52. (a) D. Azarifar, S.M. Khatami, M.A. Zolfigol, R. Nejat-Yami, J. Iran. Chem. Soc. 11 (2014) 1223-1230; (b) D. Azarifar, S.M. Khatami, R. Nejat-Yami, J. Chem. Sci. 126 (2014) 95-101; (c) K. Eskandari, B. Karami, S. Khodabakhshi, Catal. Commun. 54 (2014) 124-130; (d) D. Azarifar, R. Nejat-Yami, M. Al Kobaisi, J. Iran. Chem. Soc. 10 (2013) 439-446; (e) F.F. Abdel-Latif, A.K.M.N. Gohar, Bull. Soc. Chim. Belg. 95 (1986) 211; (f) A. Hasaninejad, M. Shekouhy, N. Golzar, A. Zare, M.M. Doroodmand, Appl. Catal. A. Gen. 402 (2011) 11-22.

53. (a) M. Bigdeli, Chin. Chem. Lett. 21 (2010) 1180-1182; (b) A. Ilangovan, S. Malayappasamy, S. Muralidharan, S. Maruthamuthu, Chem. Cent. J. 5 (2011) 1-6; (c) H.N. Karade, M. Sathe, M.P. Kaushik, Arkivoc. Xii (2007) 252-258; (d) D.M. Pore, T.S. Shaikh, N.G. Patil, S.B. Dongare, U.V. Desai, Synth. Commun. 40 (2010) 2215-2219.

54. (a) Kh. Niknam, A. Piran, Green \& Sustain. Chem. 3 (2013) 1-8; (b) M.M. Heravi, N. Javanmardi, H.A.Oskooie, B. Baghernejad, GU. J. Sci. 24 (2011) 227-231; (c) M.M. Heravi, A. Ghods, F. Derikvand, K. Bakhtiari, F.F. Bamoharram, J. Iran. Chem. Soc. 7 (2010) 615-620. 


\title{
Applications of a novel nano magnetic catalyst in the synthesis of 1,8- dioxo-octahydroxanthene and dihydropyrano[2,3-c]pyrazole derivatives
}

\author{
Mohammad Ali Zolfigol ${ }^{*}$,, Roya Ayazi-Nasrabadi ${ }^{\mathrm{a}}$, Saeed Baghery ${ }^{\mathrm{a}}$, Vahid Khakyzadeh ${ }^{\mathrm{b}}$, Saeid Azizian $^{\mathrm{c}}$
}

The design and synthesis of imidazole-based ionic liquid-stabilized on silica coated $\mathrm{Fe}_{3} \mathrm{O}_{4}$ magnetic nano particles [nano- $\mathrm{Fe}_{3} \mathrm{O}_{4} @ \mathrm{SiO}_{2} @\left(\mathrm{CH}_{2}\right)_{3}$-Imidazole- $\left.\mathrm{SO}_{3} \mathrm{H}\right] \mathrm{Cl}$ as a novel heterogeneous acidic catalyst and its applications in the preparation of 1,8-dioxo-octahydroxanthene and dihydropyrano[2,3-c]pyrazole derivatives.

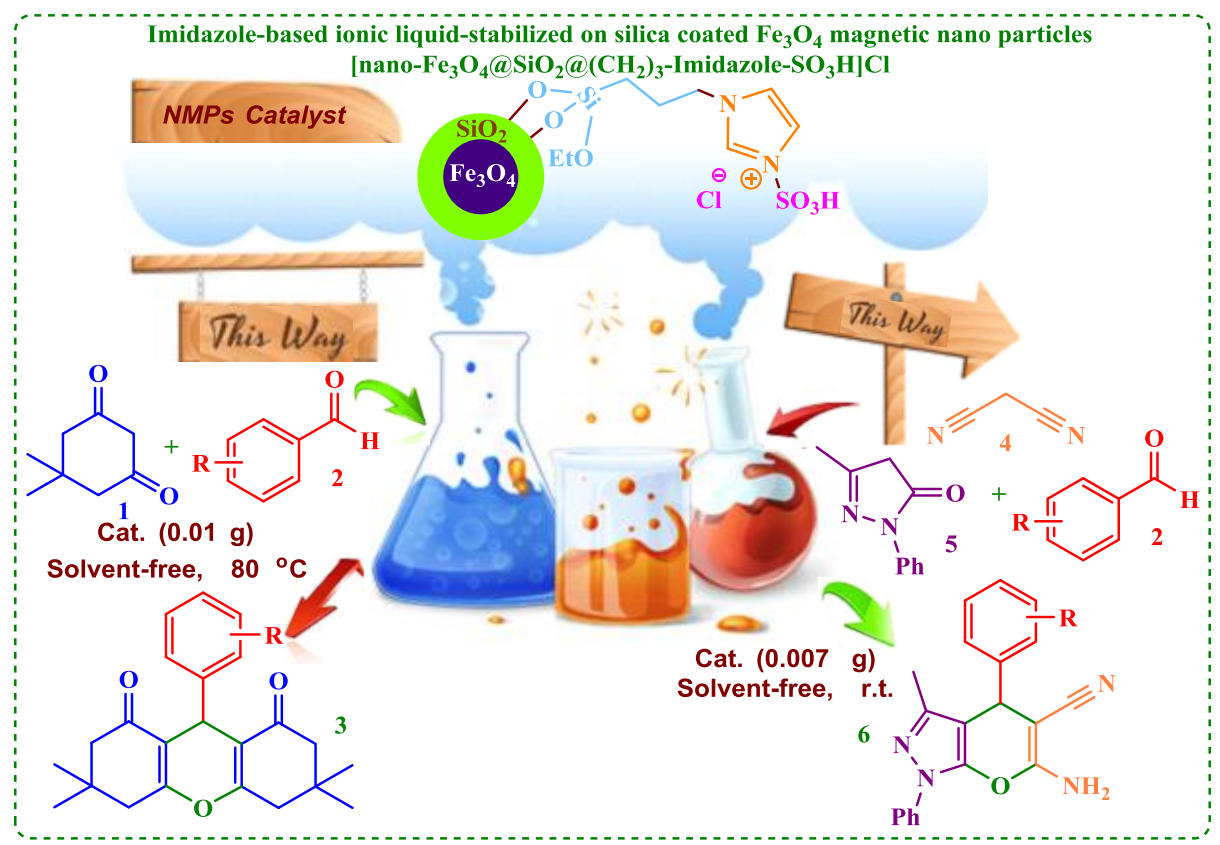

${ }^{a}$ Department of Organic Chemistry, Faculty of Chemistry, Bu-Ali Sina University, Hamedan 6517838683, Iran

${ }^{\mathrm{b}}$ Faculty of Science, Department of Chemistry, K. N.Toosi University, P.O. Box 15875-4416, Tehran, I. R. Iran ${ }^{\mathrm{c}}$ Department of Physical Chemistry, Faculty of Chemistry, Bu-Ali Sina University, Hamedan 6517838683, Iran *Corresponding Author: Fax: +988138380709

E-mail: zolfi@basu.ac.ir and mzolfigol@yahoo.com (M.A. Zolfigol). 